\title{
As3MT and GST Polymorphisms Influencing Arsenic Metabolism in Human Exposure to Drinking Groundwater
}

\author{
Farith González-Martínez ${ }^{1,2}{ }^{\mathbb{D}}$, Daniel Sánchez-Rodas ${ }^{3} \mathbb{D}$, Nelson M. Varela ${ }^{2,4} \mathbb{D}^{1}$, \\ Christopher A. Sandoval ${ }^{4}$, Luis A. Quiñones ${ }^{2,4, *}$ and Boris Johnson-Restrepo ${ }^{1, *}$ \\ 1 Environmental Chemistry Research Group and Public Health Research Group, University of Cartagena, \\ Cartagena 130015, Colombia; fgonzalezm1@unicartagena.edu.co \\ 2 Latin American Network for Implementation and Validation of Clinical Pharmacogenomics \\ Guidelines (RELIVAF-CYTED), 28015 Madrid, Spain; nvarela@med.uchile.cl \\ 3 Center for Research in Sustainable Chemistry, CIQSO, University of Huelva, 21071 Huelva, Spain; \\ rodas@dqcm.uhu.es \\ 4 Laboratory of Chemical Carcinogenesis and Pharmacogenetics (CQF), Department of Basic-Clinical \\ Oncology (DOBC), Faculty of Medicine, University of Chile, Santiago 8320000, Chile; \\ chris.sandovalp@gmail.com \\ * Correspondence: lquinone@med.uchile.cl (L.A.Q.); bjohnsonr@unicartagena.edu.co (B.J.-R.); \\ Tel.: +56-2-297-707-4144 (L.A.Q.); +57-301-363-5979 (B.J.-R.)
}

Received: 3 June 2020; Accepted: 24 June 2020; Published: 8 July 2020

\begin{abstract}
The urinary arsenic metabolites may vary among individuals and the genetic factors have been reported to explain part of the variation. We assessed the influence of polymorphic variants of Arsenic-3-methyl-transferase and Glutathione-S-transferase on urinary arsenic metabolites. Twenty-two groundwater wells for human consumption from municipalities of Colombia were analyzed for assessed the exposure by lifetime average daily dose (LADD) $(\mu \mathrm{g} / \mathrm{kg} \mathrm{bw} /$ day). Surveys on 151 participants aged between 18 and 81 years old were applied to collect demographic information and other factors. In addition, genetic polymorphisms (GSTO2-rs156697, GSTP1-rs1695, As3MT-rs3740400, GSTT1 and GSTM1) were evaluated by real time and/or conventional PCR. Arsenic metabolites: $\mathrm{As}^{\mathrm{III}}, \mathrm{As}^{\mathrm{V}}$, monomethylarsonic acid (MMA), and dimethylarsinic acid (DMA) were measured using HPLC-HG-AFS. The influence of polymorphic variants, LADD and other factors were tested using multivariate analyses. The median of total arsenic concentration in groundwater was of $33.3 \mu \mathrm{g} / \mathrm{L}$ and the median of LADD for the high exposure dose was $0.33 \mu \mathrm{g} / \mathrm{kg}$ bw/day. Univariate analyses among arsenic metabolites and genetic polymorphisms showed MMA concentrations higher in heterozygous and/or homozygous genotypes of As3MT compared to the wild-type genotype. Besides, DMA concentrations were lower in heterozygous and/or homozygous genotypes of GSTP1 compared to the wild-type genotype. Both DMA and MMA concentrations were higher in GSTM1-null genotypes compared to the active genotype. Multivariate analyses showed statistically significant association among interactions gene-gene and gene-covariates to modify the MMA and DMA excretion. Interactions between polymorphic variants As3MT*GSTM1 and GSTO2*GSTP1 could be potential modifiers of urinary excretion of arsenic and covariates as age, LADD, and alcohol consumption contribute to largely vary the arsenic individual metabolic capacity in exposed people.
\end{abstract}

Keywords: arsenic; urinary arsenic metabolites; arsenic speciation; polymorphic variants; arsenic-3methyl-transferase; glutathione-S-transferase 


\section{Introduction}

The exposure to inorganic arsenic species (InAs) such as trivalent $\left(\mathrm{As}^{\mathrm{III}}\right)$ and pentavalent $\left(\mathrm{As}^{\mathrm{V}}\right.$ ) through drinking groundwater is a global public health issue leading to chronic toxicological effect in humans [1-3]. The As ${ }^{\mathrm{III}}$ corresponds to arsenite species: $\mathrm{AsO}_{3}{ }^{3-}, \mathrm{HAsO}_{3}{ }^{2-}, \mathrm{H}_{2} \mathrm{AsO}_{3}{ }^{-}$and $\mathrm{H}_{3} \mathrm{AsO}_{3}$ while $\mathrm{As}^{\mathrm{V}}$ denotes arsenate species: $\mathrm{AsO}_{4}{ }^{3-}, \mathrm{HAsO}_{4}{ }^{2-}, \mathrm{H}_{2} \mathrm{AsO}_{4}{ }^{-}$and $\mathrm{H}_{3} \mathrm{AsO}_{4}$. Inorganic arsenic species are classified by the International Agency for Research on Cancer as Group I type compounds [4]. The World Health Association has recommended a safe level of $10 \mu \mathrm{g} / \mathrm{L}$ as a guideline in drinking water [5]. Reports in several countries of Latin America have shown concentrations of arsenic in groundwater above this risk level [1,6-8] and the distribution of arsenic in soils, sediments, vegetables and irrigation water has been recently reviewed in Colombia [9] and Brazil [10]. The presence of arsenic in soils and waters naturally may occur, although anthropogenic activities have been the main contributory factor to the environmental contamination by arsenic, soils naturally enriched by arsenic need more attention.

The metabolism of arsenic in the human body has been proposed through two pathways. The classical pathway suggests a process of sequential reduction and oxidative methylation. InAs is quickly absorbed as arsenite ( $\left.\mathrm{As}^{\mathrm{III}}\right)$ or arsenate $\left(\mathrm{As}^{\mathrm{V}}\right)$ in the gastrointestinal tract, where these species are methylated to monomethylarsonic acid (MMA) and dimethylarsinic acid (DMA). MMA and DMA metabolites are less toxic than both inorganic species and more readily excreted in urine [11,12]. The second proposed pathway suggests that arsenic either binds to certain proteins [13] or conjugates with glutathione [14] and after subsequent methylation steps results into two final products: (MMA ${ }^{\mathrm{V}}$ and $\mathrm{DMA}^{\mathrm{V}}$ ).

The percentages of urinary excretion of arsenic species in humans have been used as biomarkers of the individual metabolic capacity. Therefore, part of the interindividual variation among these species in urine may be due to habits and/or environmental factors such as smoking, alcohol consumption, diet, frequency and duration of arsenic exposure, and demographic, anthropometric factors such as age, sex, body mass index (BMI) and pregnancy $[15,16]$. In the last decade a series of genetic factors, including genetic polymorphisms in metabolic enzymes have been reported to explain the variation in the arsenic methylation capacity of humans $[2,8,17]$.

The main enzymes involved in the arsenic metabolism are classified in three groups: purine nucleoside phosphorylase (PNP), arsenic methyltransferase (AS3MT), and glutathione-S-transferases (GSTs), all of them having genetic polymorphisms [18,19]. PNP enzymes has been proposed as reducing agents of $\mathrm{As}^{\mathrm{V}}$ [20], expression of As3MT probably plays an important role in the methylation of $\mathrm{As}^{\mathrm{III}}$ [21,22], and GST are a series of phase II enzymes that detoxify xenobiotics via conjugation reaction with glutathione (GSH). Four members from the GST family including GSTO (isoforms 1 and 2), GSTP1, GSTT1 and GSTM1 could influence the capacities to metabolize arsenic, according the expression level and the presence of different allele variants $[2,23,24]$. GSTO ( $\omega$ class) omega 1 reduces pentavalent and methylated arsenic species [25]. Moreover, the GSTO omega 2 reduces only methylated species [26]. Besides, low activity of GSTP1 ( $\pi$ class) enzyme could decrease the detoxification function of GSH [27] and the enzymes GSTT1 ( $\theta$ class) and GSTM1 ( $\mu$ class) may facilitate the methylation of inorganic arsenic. Therefore, the absence of their activity could increase the urinary excretion of inorganic arsenic [28] (Figure 1).

Polymorphic variants of GST and As3MT genes influence the arsenic metabolism giving rise to inter-individual differences. These polymorphic variants are likely to decrease the enzymatic activity, increasing the toxicity of inorganic arsenic, though for GSTP1 gene the findings were not consistent [29,30]. The GSTT1-null and GSTM1-null genetic polymorphisms have also been suggested as participants in the arsenic metabolism. Nevertheless, its effects are minors [2,31]. Conversely, As3MT and GSTO are polymorphisms that have the most evidence associated with the capacities to metabolize arsenic, through the increasing in the expression of the enzymatic activity responsible for the methylation of inorganic arsenic [32-35]. Genetic polymorphisms in these enzymes have been shown to have differences in frequencies (genotypic and allelic) worldwide, depending on ethnicity/race [36,37]. 


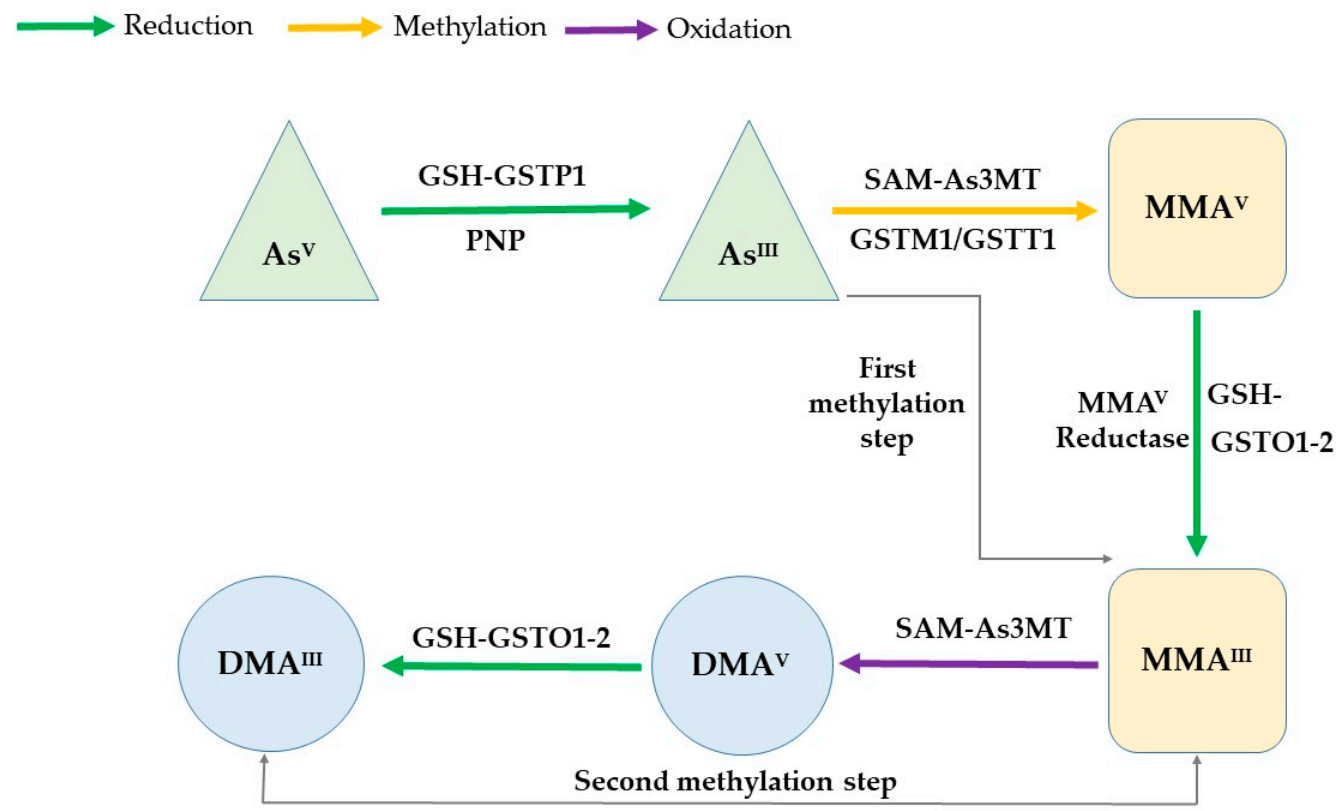

Figure 1. The classical pathway for explain the mechanism of arsenic metabolism. The $\mathrm{As}^{\mathrm{V}}$ is reducing to As ${ }^{\mathrm{III}}$ through a conjugation reaction among Glutathione (GSH as the electron donor) and Glutathione-S-transferase enzymes (GSTP1), as well as purine nucleoside phosphorylase (PNP) enzymes. As ${ }^{\mathrm{III}}$ species are methylated to monomethylarsonic acid $\left(\mathrm{MMA}^{\mathrm{V}}\right)$ and dimethylarsinic acid $\left(\mathrm{DMA}^{\mathrm{V}}\right)$. The enzyme participant is Arsenic (+3)-methyl-transferase (As3MT), using S-adenosyl-methionine (SAM-methyl donor). GSH and GSTO1-2 involve in a conjugated reaction to form the intermediate products monomethylarsonous acid $\left(\mathrm{MMA}^{\mathrm{III}}\right)$ and dimethylarsinous acid (DMA ${ }^{\mathrm{III}}$ ). The MMA reductase enzyme is responsible for the reduction of $\mathrm{MMA}^{\mathrm{V}}$ to $\mathrm{MMA}^{\mathrm{III}}$.

Previous work performed by our group showed that polymorphisms of GSTP1(rs1695) increase urinary inorganic arsenic and decrease the primary methylation index in Colombian study population exposed to low and high arsenic concentrations from drinking groundwater [8]. However, the polymorphisms GSTO and As3MT have not been evaluated, which play an important role in the methylation of inorganic arsenic. There are some knowledge gaps in the arsenic metabolism that have been not elucidated yet. Hence, it is necessary to clarify relationship among metabolites and genotypes.

Therefore, it is necessary to study in the Colombian study population, the polymorphic variant frequencies and their effect on methylation capacity to establish intracellular retention rates of inorganic arsenic. Therefore, the aim of this study was to evaluate the influence of As3MT and GSTs polymorphic variants on urinary arsenic metabolites and their possible combined effect with the demographic, anthropometric and lifestyles factors.

\section{Results}

\subsection{Study Population Characterization}

Regarding the demographics, all participants had a mean age of $41.8 \pm 13.6$ years, being statistically greater in the high exposure group $(44.8 \pm 14.1)$ than the low exposure group $(40.3 \pm 13.3),(p=0.02)$. The subjects were mostly women $(71.5 \%)$ and gender was not different between the two groups. BMI was lower in the high exposure group compared to the low exposure group $(p<0.01)$. Results for total arsenic in water was statistically different among the high exposure group ( $35.5 \mu \mathrm{g} / \mathrm{L}$ ) and low exposure group $(10 \mu \mathrm{g} / \mathrm{L}),(p<0.01)$. Urinary concentrations of DMA were significantly greater in the high exposure group compared to low exposure group $(p=0.03)$ while total arsenic $(\mu \mathrm{g} / \mathrm{g}$ creatinine) was not different between groups. Likewise, the median of the analysis of genotypic frequencies for the polymorphisms evaluated was not different between groups (Table 1). 
Table 1. General characteristics of the study population.

\begin{tabular}{|c|c|c|c|c|}
\hline Characteristics & High Exposure & Low Exposure & Total & $p$-Value \\
\hline No. Subjects, n (\%) & $50(33.1)$ & $101(66.9)$ & $151(100)$ & \multirow{3}{*}{$0.77^{*}$} \\
\hline Male, n (\% Col.) a & $15(30)$ & $28(27.7)$ & $43(28.5)$ & \\
\hline Female, n (\% Col.) & $35(70)$ & $73(72.3)$ & $108(71.5)$ & \\
\hline Age years, mean $\pm \mathrm{SD}^{\mathrm{b}}$ & $44.8 \pm 14.1$ & $40.3 \pm 13.3$ & $41.8 \pm 13.6$ & $0.02 a$ \\
\hline $\mathrm{BMI}{ }^{\mathrm{c}}, \mathrm{kg} / \mathrm{m}^{2}$, mean $\pm \mathrm{SD}$ & $22.1 \pm 3.5$ & $26 \pm 4.1$ & $24.7 \pm 4.3$ & $<0.001 a$ \\
\hline Water total arsenic, $\mu \mathrm{g} / \mathrm{L}$, median (IQR) ${ }^{\mathrm{d}}$ & $35.5(31.7,37.3)$ & $10(10,10)$ & $33.3(30.9,36.7)$ & \multirow[t]{2}{*}{$<0.001+$} \\
\hline No. of wells in each place, mean & 22 & 1 & 23 & \\
\hline Residence years, median (IQR) & $17.9(14.2,20.6)$ & $15.9(14.2,20.6)$ & 16.9 & $0.32+$ \\
\hline Urinary TuAs ${ }^{\mathrm{e}}, \mu \mathrm{g} / \mathrm{g}$ creatinine, median (IQR) & $4.2(3.1,7.8)$ & $3.6(2.7,7.0)$ & $4.0(2.7,7.0)$ & $0.07+$ \\
\hline Urinary $\operatorname{InAs} \mathrm{f}, \mu \mathrm{g} / \mathrm{L}$, median $(\mathrm{IQR})$ & $0.80(0.25,1.33)$ & $0.80(0.50,1.25)$ & $0.80(0.5,1.3)$ & $0.97+$ \\
\hline Urinary MMA $g, \mu g / L$, median $(\mathrm{IQR})$ & $0.80(0.40,1.5)$ & $0.60(0.30,1.0)$ & $0.60(0.30,1.3)$ & $0.08+$ \\
\hline Urinary DMA ${ }^{h}, \mu \mathrm{g} / \mathrm{L}$, median (IQR) & $2.1(1.4,3.1)$ & $1.5(1.1,2.7)$ & $1.7(1.1,2.8)$ & $0.03+$ \\
\hline \multicolumn{5}{|l|}{ Cigarette smoking, n (\% Col.) } \\
\hline Smoker & $3(6.0)$ & $12(11.9)$ & $15(9.9)$ & \multirow{2}{*}{$0.25 *$} \\
\hline Non-smoker & $47(94)$ & $89(88.1)$ & $136(90.1)$ & \\
\hline \multicolumn{5}{|l|}{ Shellfish consumption, $\mathrm{n}(\%$ Col.) } \\
\hline$\geq 2$ per week & $4(8.0)$ & $12(11.9)$ & $16(10.6)$ & \multirow{2}{*}{$0.46^{*}$} \\
\hline$<2$ per week & $46(92)$ & $89(88.1)$ & $135(89.4)$ & \\
\hline \multicolumn{5}{|l|}{ Water consumption, $\mathrm{n}(\% \mathrm{Col})}$. \\
\hline$\geq 2$ L per day & $46(92)$ & $94(93)$ & $140(92.7)$ & \multirow{2}{*}{$0.70 *$} \\
\hline$<2$ L per day & $4(8.0)$ & $7(6.9)$ & $11(7.3)$ & \\
\hline \multicolumn{5}{|l|}{ Alcohol consumption, $\mathrm{n}(\% \mathrm{Col}$ ) } \\
\hline$\geq 5$ glass weekend & $8(16.0)$ & $29(28.7)$ & $114(75.5)$ & \multirow{3}{*}{$0.08 *$} \\
\hline None & $42(84)$ & $72(71.3)$ & $37(24.5)$ & \\
\hline \multicolumn{4}{|l|}{ Genotypes } & \\
\hline \multicolumn{5}{|l|}{ GSTT1, n (\% Col.) } \\
\hline Null & $11(22)$ & $22(21.8)$ & $33(21.9)$ & \multirow{2}{*}{$0.97 *$} \\
\hline Active & $39(78)$ & $79(78.2)$ & $118(78.2)$ & \\
\hline \multicolumn{5}{|l|}{ GSTM1, n (\% Col.) } \\
\hline Null & $18(36)$ & $29(28.7)$ & $47(31.1)$ & \multirow[b]{2}{*}{$0.36^{*}$} \\
\hline Active & $32(64)$ & $72(71.3)$ & $104(68.9)$ & \\
\hline \multicolumn{5}{|l|}{ GSTP1-rs1695, n (\% Col.) } \\
\hline $\mathrm{AG}+\mathrm{GG}$ & $26(52)$ & $62(61.4)$ & $88(58.3)$ & \multirow{2}{*}{$0.27 *$} \\
\hline AA (wild-type) & $24(48)$ & $39(38.6)$ & $63(41.7)$ & \\
\hline \multicolumn{5}{|l|}{ GSTO2-rs156697, n (\% Col.) } \\
\hline $\mathrm{TC}+\mathrm{CC}$ & $18(36)$ & $31(30.7)$ & $49(32.5)$ & \multirow{2}{*}{$0.51 *$} \\
\hline TT (wild-type) & $32(64)$ & $70(69.3)$ & $102(67.5)$ & \\
\hline \multicolumn{5}{|l|}{ AS3MT-rs3740400, n (\% Col.) } \\
\hline $\mathrm{TG}+\mathrm{GG}$ & $29(58)$ & $60(59.4)$ & $89(58.9)$ & \multirow{2}{*}{$0.86^{*}$} \\
\hline TT (wild-type) & $21(42)$ & $41(40.6)$ & $62(41.1)$ & \\
\hline
\end{tabular}

Note: ${ }^{*} \chi^{2}$-test. a t-test. + Wilcoxon rank sum test. HWE $\left(\chi^{2}\right.$-test; $\left.p>0.05\right) .{ }^{a} \%$ Col. $=$ proportion of individuals with characteristics by dividing into the total number of in each column. ${ }^{\mathrm{b}} \mathrm{SD}=$ Standard deviation. ${ }^{\mathrm{c}} \mathrm{BMI}=$ Body mass index. ${ }^{d} I Q R=$ Interquartile range defined as the range from the 25th percentile to the 75th percentile. ${ }^{\mathrm{e}} \mathrm{TuAs}=$ total urinary arsenic. ${ }^{\mathrm{f}} \mathrm{InAs}=$ inorganic arsenic $\left(\mathrm{As}^{\mathrm{III}}\right.$ and $\left.\mathrm{As}^{\mathrm{V}}\right) .{ }^{\mathrm{g}} \mathrm{MMA}=$ Monomethylarsonic acid.

${ }^{\mathrm{h}} \mathrm{DMA}=$ Dimethylarsinic acid.

\subsection{Arsenic in Drinking Groundwater and Lifetime Average Daily Dose}

Twenty-two groundwater wells from studied municipalities were analyzed for TAs in two different years. The first measurements were in September 2017, with a median of $31.5 \mu \mathrm{g} / \mathrm{L}(\mathrm{IQR}=20.6,39.2)$. The second measurements were in December 2018, with a median of $33.3 \mu \mathrm{g} / \mathrm{L}(\mathrm{IQR}=30.9,36.7)$. These values were higher than the guideline reference values of $10 \mu \mathrm{g} / \mathrm{L}$ for arsenic WHO. For the samples collected in 2018, speciation analysis was also performed for $\mathrm{As}^{\mathrm{III}}$ and $\mathrm{As}^{\mathrm{V}}$ concentrations with a median of $23.6 \mu \mathrm{g} / \mathrm{L}$ and $9.7 \mu \mathrm{g} / \mathrm{L}$ respectively. In addition, some physicochemical parameters of the groundwater were determined in order to have an overview of drinking water quality (Table S3). The population of study had an overall average of water consumption of $2.5 \mathrm{~L} /$ day for an exposure frequency of 365 days/year. The exposure duration was different between the high and low exposure groups (17.9 years and 15.9 years respectively) and the body weight average between both groups was very similar. The median of LADD for the high exposure group to arsenic by drinking groundwater was 
$0.33 \mu \mathrm{g} / \mathrm{kg}$ bw/day and the HQ 1.1 while the median of LADD for the low exposure group $0.08 \mu \mathrm{g} / \mathrm{kg}$ bw/day and the HQ 0.29 (Table S4).

\subsection{Genotype Analyses}

Polymorphisms analyzed were consistent with the frequencies expected from the Hardy-Weinberg equilibrium HWE (chi-square test; $p>0.05$ ). The analysis of genotypic and allelic frequencies for the polymorphisms evaluated showed the following results: GSTT1-null 21.9\%, GSTM1-null 31.1\%, GSTO2 wild-type $67.5 \%$, heterozygous genotypic variant $27.2 \%$ and its homozygous genotypic variant $5.3 \%$, GSTP1 wild-type $41.7 \%$, heterozygous genotypic variant $41.7 \%$ and its homozygous genotypic variant $13.3 \%$, As3MT wild-type $41.1 \%$, heterozygous genotypic genotype $41.1 \%$ and the homozygous genotypic genotype $17.9 \%$. For the allelic frequencies of GSTO2-rs156697 Alleles T/C (81/19), GSTP1-rs1695 Alleles A/G (66/34) and AS3MT-rs3740400 Alleles T/G (62/38). In the Table S5 genotypic and allelic frequencies found were compared with other populations studied of Latin American and worldwide. The data showed the variability of each individual independent of their ancestrality.

\subsection{Total Urinary and Arsenic Species}

The Table S6 shows multiple comparisons of urinary arsenic metabolites, corrected by Bonferroni test and adjusted by age and BMI. Changes were observed to MMA $(p=0.04)$ and TuAs $(p=0.02)$ for the differences between high exposure and low exposure groups. Additionally, sample size effect test or Cohen's d was calculated for each comparison of arsenic metabolite concentrations among the groups (InAs d = 0.21; DMA d =0.53; MMA d = 0.52; and TuAs d $=0.48$ ).

\subsection{Univariate Analyses of Polymorphisms and Covariates on Urinary Arsenic Metabolites}

Concentrations of urinary arsenic species were compared for genotypes by Wilcoxon rank-sum test and the significance levels were adjusted with the Bonferroni test which showed some statistically significant results as reported in the Table S7. GSTP1 gene was associated with the urinary excretion of DMA ( $p=0.04)$, As3MT gene was associated with MMA $(p=0.04)$, and GSTM1 gene was associated with both DMA $(p=0.02)$ and MMA $(p=0.02)$. The influence of GST and As3MT polymorphic variants on urinary concentrations of arsenic metabolites, were evaluated separately by simple Dirichlet regression in a first model in Table 2. The results showed that the GSTT1-null variant was associated with InAs, MMA and DMA indicating an increase of InAs $(p=0.04)$ and MMA $(p=0.01)$, and a decrease of DMA $(p<0.01)$. Moreover, the GSTM1-null variant showed associated with DMA, indicating an increase $(p<0.01)$. Similarly, the heterozygous/homozygous genotypes of the GSTO2 and As3MT were associated with lower urinary arsenic concentrations of DMA. GSTP1 and As3MT genes had associated with InAs, indicating an increase. The univariate analyses of covariates were significant for MMA with gender $(p=0.04)$ and InAs with alcohol consumption $(p=0.03)$ (Table S8). Results of the univariate analyses are shown in Table 3. 
Table 2. Univariate analyses of polymorphic variants GST and As3MT on urinary arsenic metabolites.

\begin{tabular}{|c|c|c|c|c|c|c|c|c|c|c|}
\hline \multirow{3}{*}{ Genotypes } & \multirow[b]{3}{*}{$n$} & \multicolumn{9}{|c|}{ Urinary Arsenic Species } \\
\hline & & \multicolumn{3}{|c|}{$\operatorname{InAs}{ }^{b}$} & \multicolumn{3}{|c|}{ MMA $^{c}$} & \multicolumn{3}{|c|}{ DMA $^{d}$} \\
\hline & & $\beta$ & $\mathrm{SE}^{\mathrm{a}}$ & $p$-Value & $\beta$ & SE & $p$-Value & $\beta$ & SE & $p$-Value \\
\hline $\begin{array}{l}\text { GSTT1 } \\
\text { Null } \\
\text { Active }\end{array}$ & $\begin{array}{c}33 \\
118\end{array}$ & $\begin{array}{l}0.34 \\
\text { ref. }\end{array}$ & 0.29 & $0.04^{*}$ & $\begin{array}{l}0.45 \\
\text { ref. }\end{array}$ & 0.17 & $0.01 *$ & $\begin{array}{l}0.47 \\
\text { ref. }\end{array}$ & 0.16 & $0.004^{*}$ \\
\hline $\begin{array}{c}\text { GSTM1 } \\
\text { Null } \\
\text { Active }\end{array}$ & $\begin{array}{c}47 \\
104\end{array}$ & $\begin{array}{l}0.24 \\
\text { ref. }\end{array}$ & 0.16 & 0.13 & $\begin{array}{c}0.17 \\
\text { ref. }\end{array}$ & 0.16 & 0.27 & $\begin{array}{l}0.39 \\
\text { ref. }\end{array}$ & 0.15 & $0.009 *$ \\
\hline $\begin{array}{c}\text { GSTP1 (rs1695) } \\
\text { AG + GG } \\
\text { AA (wild-type) }\end{array}$ & $\begin{array}{l}83 \\
68\end{array}$ & $\begin{array}{l}0.46 \\
\text { ref. }\end{array}$ & 0.15 & $0.002 *$ & $\begin{array}{c}0.08 \\
\text { ref. }\end{array}$ & 0.15 & 0.58 & $\begin{array}{c}0.02 \\
\text { ref. }\end{array}$ & 0.14 & 0.86 \\
\hline $\begin{array}{c}\text { GSTO2 (rs156697) } \\
\text { TC + CC } \\
\text { TT (wild-type) } \\
\text { As3MT(rs374040) }\end{array}$ & $\begin{array}{c}49 \\
102\end{array}$ & $\begin{array}{l}0.03 \\
\text { ref. }\end{array}$ & 0.15 & 0.84 & $\begin{array}{l}-0.07 \\
\text { ref. }\end{array}$ & 0.16 & 0.61 & $\begin{array}{l}-0.47 \\
\text { ref. }\end{array}$ & 0.15 & $0.001 *$ \\
\hline $\begin{array}{c}\text { TG + GG } \\
\text { TT (wild-type) }\end{array}$ & $\begin{array}{l}89 \\
62\end{array}$ & $\begin{array}{c}-0.58 \\
\text { ref. }\end{array}$ & 0.15 & $<0.001 *$ & $\begin{array}{c}-0.24 \\
\text { ref. }\end{array}$ & 0.15 & 0.11 & $\begin{array}{c}-0.63 \\
\text { ref. }\end{array}$ & 0.14 & $<0.001$ * \\
\hline
\end{tabular}

Note: $\beta=$ regression coefficient of genetic dominant model compared to the wild-type on urinary arsenic species in genotypic substitutions and genetic basic model null compared to active in genotypic deletions. * Statistical significance univariate analysis through Dirichlet regression $(p<0.05) ;{ }^{\mathrm{a}} \mathrm{SE}=$ Standard error; ${ }^{\mathrm{b}} \mathrm{InAs}=$ inorganic arsenic $\left(\mathrm{As}^{\mathrm{III}}\right.$ and $\left.\mathrm{As}^{\mathrm{V}}\right) ;{ }^{\mathrm{c}} \mathrm{MMA}=$ monomethylarsonic acid; ${ }^{\mathrm{d}} \mathrm{DMA}=$ dimethylarsinic acid.

Table 3. Univariate analyses of demographic characteristics and lifestyle on urinary arsenic metabolites.

\begin{tabular}{|c|c|c|c|c|c|c|c|c|c|c|}
\hline \multirow{3}{*}{ Covariates } & \multicolumn{10}{|c|}{ Urinary Arsenic Species } \\
\hline & \multicolumn{4}{|c|}{ InAs ${ }^{b}$} & \multicolumn{3}{|c|}{ MMA $^{c}$} & \multicolumn{3}{|c|}{ DMA $^{d}$} \\
\hline & $n$ & $\beta$ & $\mathrm{SE}^{\mathrm{a}}$ & $p$-Value & B & SE & $p$-Value & $\beta$ & SE & $p$-Value \\
\hline TAs in water $(\mu \mathrm{g} / \mathrm{L})$, median (range) & $26.1(10,39.4)$ & -0.09 & 0.77 & 0.24 & -0.03 & 0.52 & 0.55 & 0.12 & 0.09 & 0.18 \\
\hline $\operatorname{LADD}(\mu \mathrm{g} / \mathrm{kg}-\mathrm{bw} / \mathrm{d})$, median (range) & $0.23(0.09,0.34)$ & -10.3 & 7.9 & 0.19 & 0.64 & 7.5 & 0.93 & 9.6 & 9.5 & 0.31 \\
\hline $\begin{array}{c}\text { Urinary TuAs }{ }^{\mathrm{e}} \\
\text { ( } \mu \mathrm{g} / \mathrm{g} \text { creat.), median (range) }\end{array}$ & $4.0(2.7,7.0)$ & -0.03 & 12.5 & 0.84 & 0.18 & 0.08 & $0.03^{*}$ & -0.15 & 0.15 & 0.29 \\
\hline Age (years), mean $\pm \mathrm{SD}^{\mathrm{f}}$ & $41.8 \pm 13.6$ & -0.12 & 0.08 & 0.10 & -0.05 & 0.05 & 0.32 & 0.18 & 0.09 & $0.04^{*}$ \\
\hline $\begin{array}{c}\mathrm{BMI} \\
\mathrm{Sex}\end{array}$ & $24.7 \pm 4.3$ & -11 & 0.24 & 0.64 & -0.14 & 16.4 & 0.39 & 0.25 & 0.28 & 0.37 \\
\hline $\begin{array}{l}\text { Female } \\
\text { Male }\end{array}$ & $\begin{array}{c}43 \\
108\end{array}$ & $\begin{array}{c}-1.44 \\
\text { ref. }\end{array}$ & 2.3 & 0.53 & $\begin{array}{l}-0.98 \\
\text { ref. }\end{array}$ & 1.6 & 0.53 & $\begin{array}{l}2.41 \\
\text { ref. }\end{array}$ & 2.7 & 0.37 \\
\hline \multicolumn{11}{|l|}{ Smoking Habit } \\
\hline $\begin{array}{l}\text { Yes } \\
\text { No }\end{array}$ & $\begin{array}{c}15 \\
136\end{array}$ & $\begin{array}{l}-1.56 \\
\text { ref. }\end{array}$ & 3.5 & 0.65 & $\begin{array}{l}-2.92 \\
\text { ref. }\end{array}$ & 2.4 & 0.22 & $\begin{array}{l}4.5 \\
\text { ref. }\end{array}$ & 4.1 & 0.27 \\
\hline \multicolumn{11}{|l|}{ Alcohol consumption } \\
\hline $\begin{array}{l}\geq 5 \text { glass per week } \\
\text { No consumption }\end{array}$ & $\begin{array}{c}37 \\
114\end{array}$ & $\begin{array}{l}-0.23 \\
\text { ref. }\end{array}$ & 2.4 & 0.92 & $\begin{array}{l}-1.73 \\
\text { ref. }\end{array}$ & 1.6 & 0.29 & $\begin{array}{l}1.95 \\
\text { ref. }\end{array}$ & 2.8 & 0.49 \\
\hline \multicolumn{11}{|l|}{ Water consumption } \\
\hline $\begin{array}{l}\geq 2 \text { L per day } \\
<2 \text { L per day }\end{array}$ & $\begin{array}{c}140 \\
11\end{array}$ & $\begin{array}{l}1.06 \\
\text { ref. }\end{array}$ & 3.9 & 0.79 & $\begin{array}{c}0.64 \\
\text { ref. }\end{array}$ & 2.7 & 0.81 & $\begin{array}{c}-1.72 \\
\text { ref. }\end{array}$ & 4.7 & 0.72 \\
\hline \multicolumn{11}{|l|}{ Shellfish and/or fish } \\
\hline $\begin{array}{l}\geq 2 x \text { per week } \\
<2 x \text { per week }\end{array}$ & $\begin{array}{c}16 \\
135\end{array}$ & $\begin{array}{l}-4.2 \\
\text { ref. }\end{array}$ & 3.6 & 0.24 & $\begin{array}{l}1.19 \\
\text { ref. }\end{array}$ & 2.4 & 0.63 & $\begin{array}{l}3.03 \\
\text { ref. }\end{array}$ & 4.2 & 0.47 \\
\hline
\end{tabular}

Note: $\beta=$ regression coefficient of related covariates categories compared to unrelated covariates categories on urinary arsenic species. ${ }^{*}$ Statistical significance univariate analysis through Dirichlet regression $(\mathrm{p}<0.05) ;{ }^{\mathrm{a}} \mathrm{SE}=\mathrm{Standard}$ error. ${ }^{\mathrm{b}}$ InAs =Inorganic arsenic $\left(\mathrm{As}{ }^{\mathrm{III}}\right.$ and $\left.\mathrm{As}^{\mathrm{V}}\right) .{ }^{\mathrm{c}} \mathrm{MMA}=$ Monomethylarsonic acid. ${ }^{\mathrm{d}} \mathrm{DMA}=$ Dimethylarsinic acid. ${ }^{\mathrm{e}} \mathrm{TuAs}=$ total urinary arsenic by creatinine adjusted. ${ }^{\mathrm{f}} \mathrm{SD}=$ Standard deviation. ${ }^{\mathrm{g}} \mathrm{BMI}=$ Body mass index.

\subsection{Multivariate Analyses of Polymorphisms and Covariates on Urinary Arsenic Metabolites}

Multivariate Dirichlet regressions of the relationship between urinary arsenic metabolites and genotypes were performed and shown in Figures 2-4. Interdependence among the three urinary arsenic metabolites and the total urinary arsenic concentration was adjusted by genotypes, showing the impact of the methylation efficiency in the toxicity of arsenic (Figure 2). For the heterozygous/homozygous variant of GSTO2, \%DMA was lower compared to the wild-type and tend to increase proportionally with the increase of total urinary arsenic, while that \%MMA trend to decrease. For the heterozygous/homozygous variant of GSTP1, \%DMA was lower compared to the wild-type and decreased proportionally with the increase in total urinary arsenic. Similarly, \%MMA tend to decrease their concentration with the increase of total urinary arsenic concentration. 


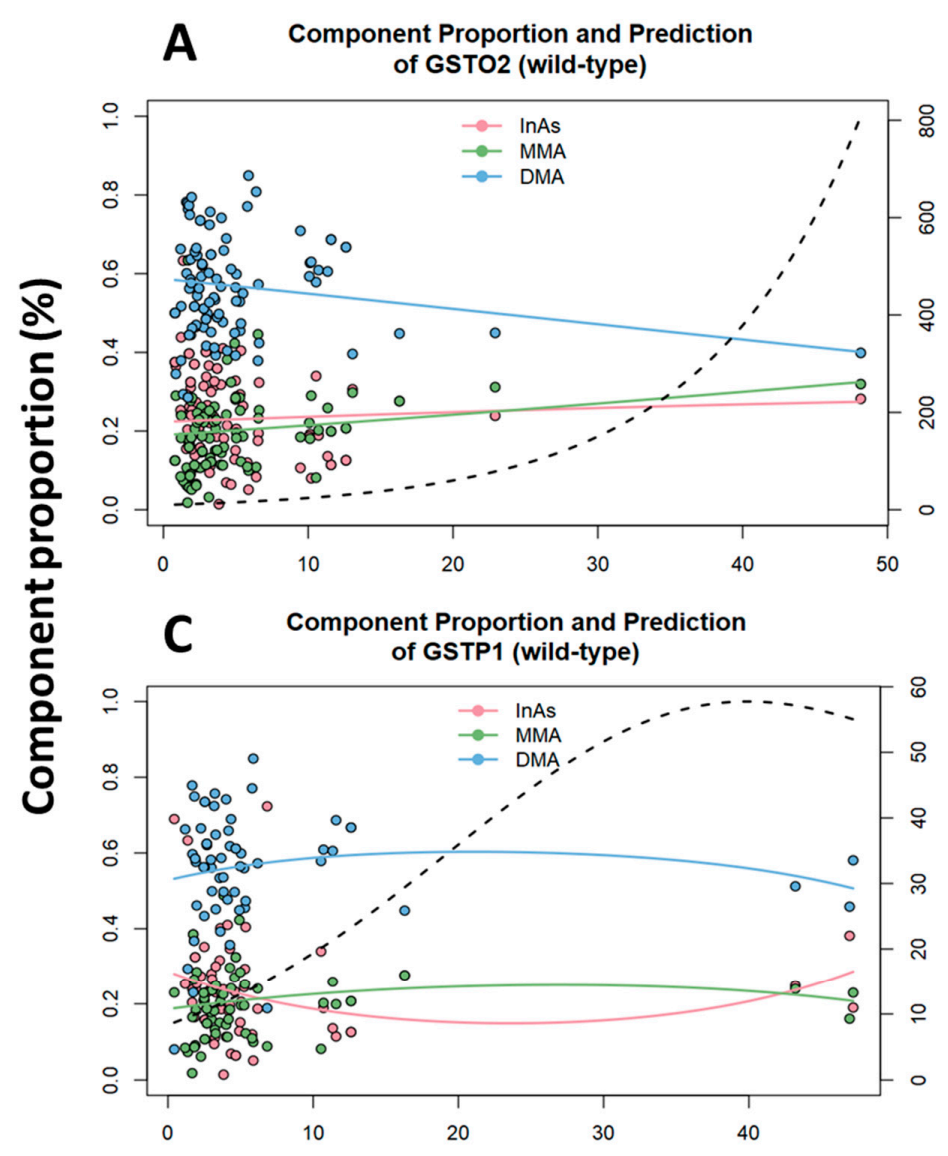

B Component Proportion and Prediction

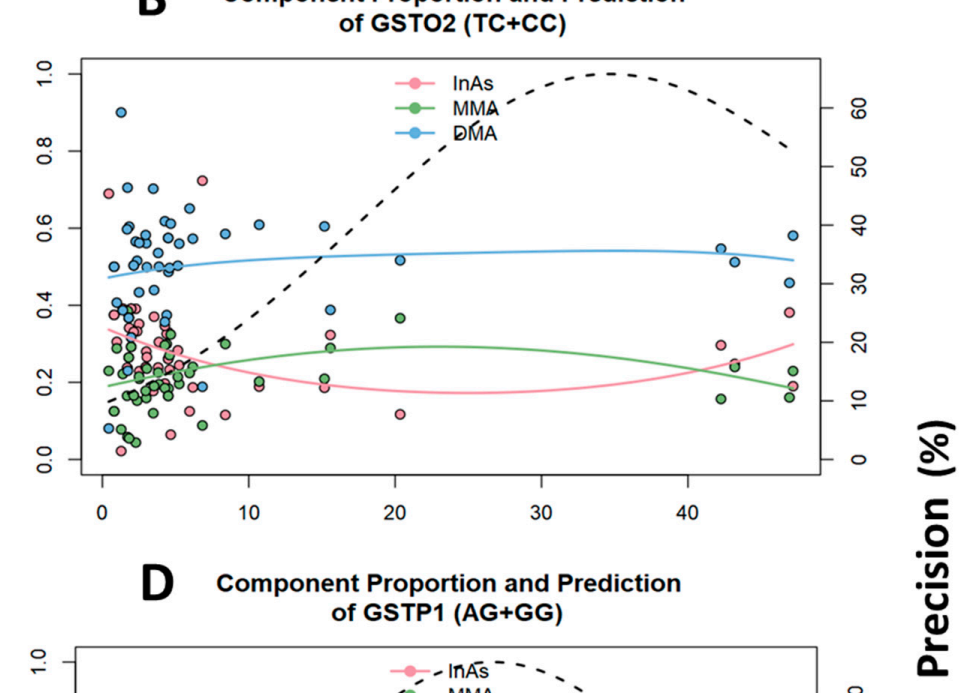

TuAs ( $\mu \mathrm{g} / \mathrm{g}$ creatinine)

Figure 2. Multivariate Dirichlet regression on the relationship among the urinary arsenic metabolites and total urinary As concentration by genotype adjusted. (A) Wild-type genotype of GSTO2: InAs $(p<0.01)$, MMA $(p=0.01)$ and DMA $(p<0.01)$. (B) Heterozygous+ homozygous genotypes of GSTO2: InAs $(p=0.27)$, MMA $(p<0.01)$ and DMA $(p=0.01)$. C. Wild-type genotype of GSTP1: InAs $(p=0.51)$, MMA $(p=0.02)$ and DMA $(p=0.03)$. D. Heterozygous + homozygous genotypes of GSTP1: InAs ( $p=0.15)$, MMA $(p<0.01)$ and DMA $(p<0.01)$. 

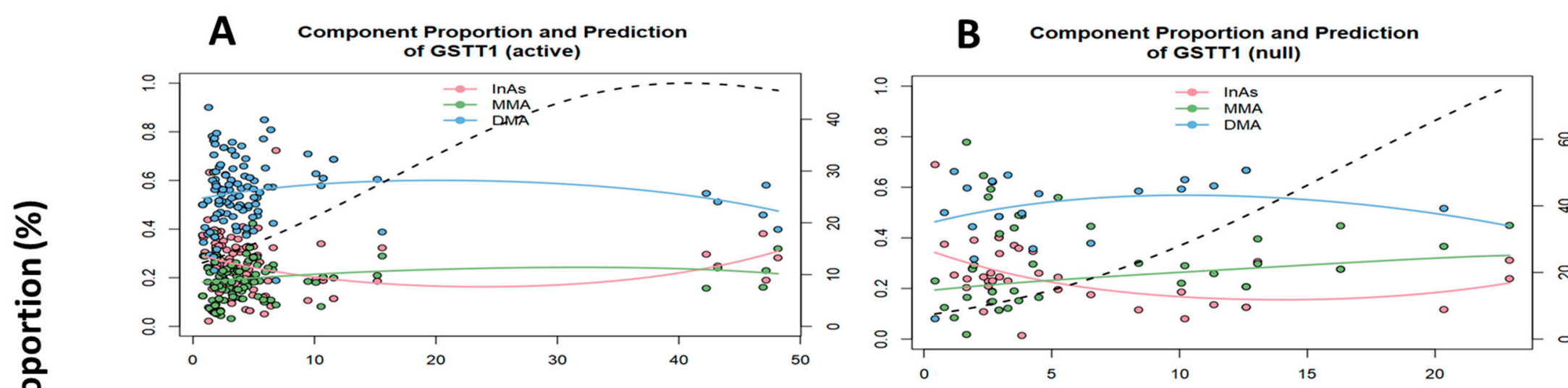

C Component Proportion and Prediction of GSTM1 (active)

D Component Proportion and Prediction

들
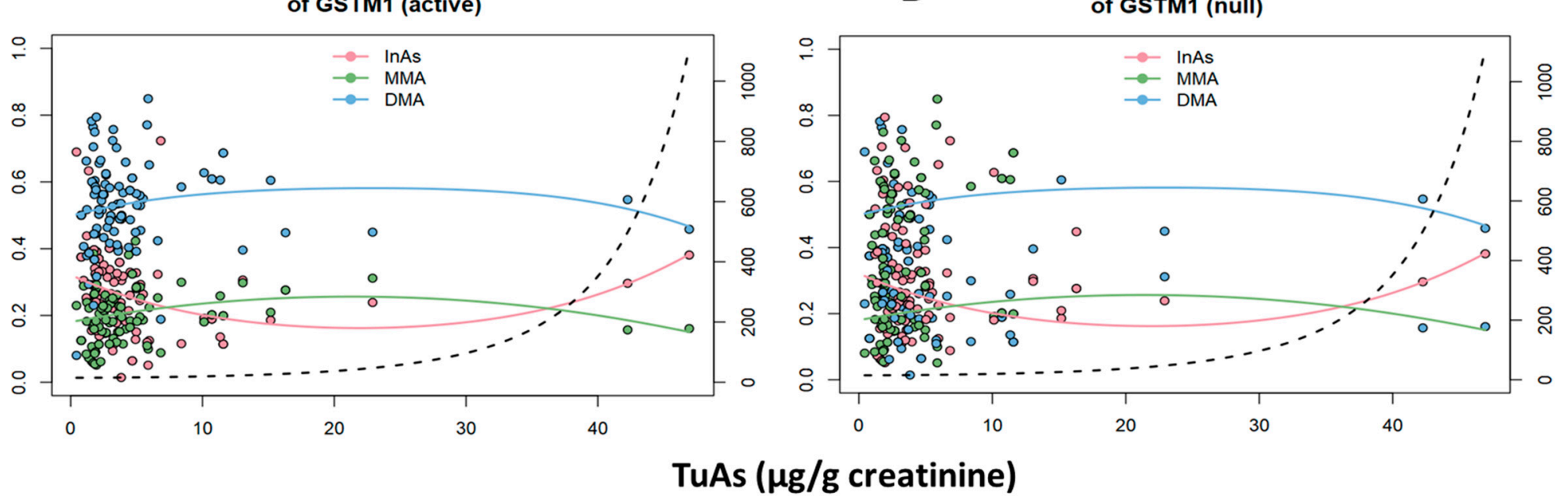

TuAs ( $\mu \mathrm{g} / \mathrm{g}$ creatinine)

Figure 3. Multivariate Dirichlet regression on the relationship among the urinary arsenic metabolites and urinary As concentration by genotype adjusted. (A) Active GSTT1: InAs $(p=0.70)$, MMA $(p=0.03)$, DMA $(p=0.05)$. (B) Null GSTT1: InAs $(p=0.71)$, MMA $(p=0.07)$, DMA $(p=0.08)$ (C) Active GSTM1: InAs $(p=0.32)$, MMA $(p=0.38)$, DMA $(p=0.53)(\mathbf{D})$ Null GSTM1: InAs $(p=0.06)$, MMA $(p<0.01)$, DMA $(p<0.01)$. 


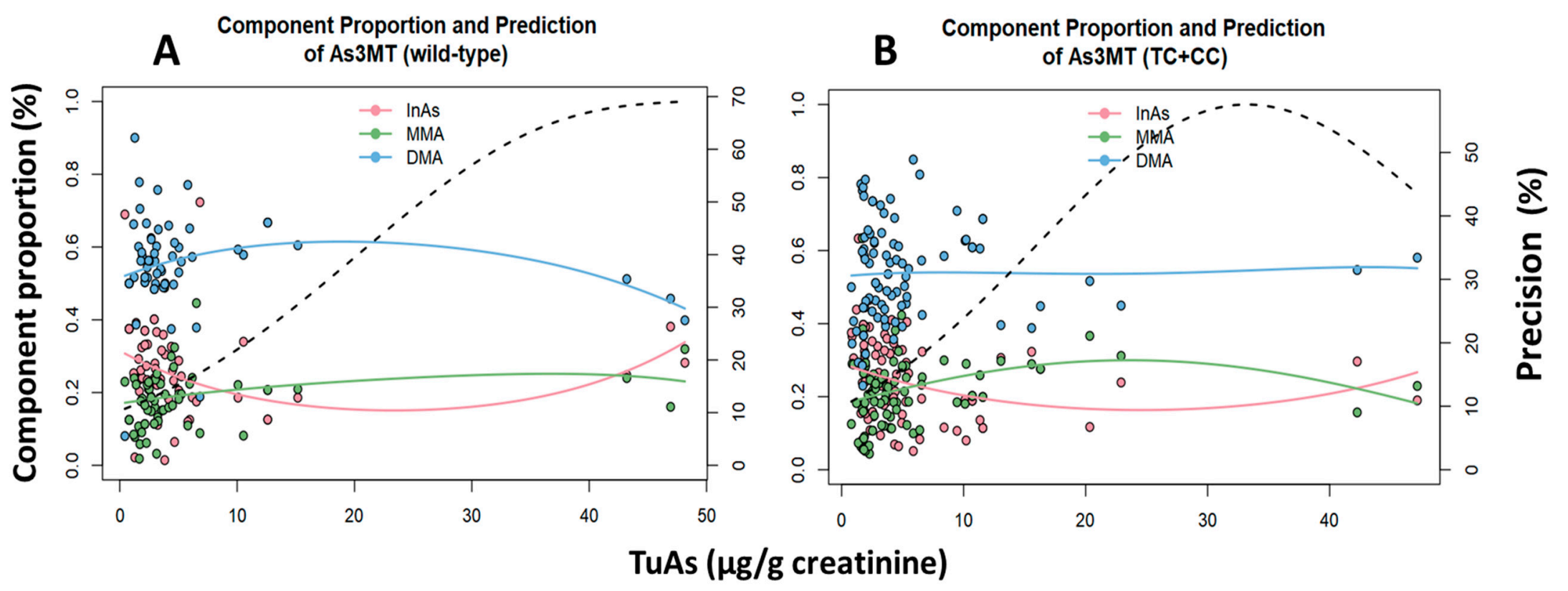

Figure 4. Multivariate Dirichlet regression on the relationship among the urinary arsenic metabolites and urinary As concentration by genotype adjusted. (A) Wild-type genotype of As3MT; InAs $(p=0.18)$, MMA $(p<0.01)$, DMA $(p<0.01)$. (B) Heterozygous+ homozygous genotypes of $A s 3 M T$ : InAs $(p=0.70)$, MMA $(p=0.06)$, DMA $(p=0.08)$. 
For GSTT1 gene, the Figure 3 showed for the active variant a decreasing trend for \%DMA, as well as a total urinary arsenic concentration increase, while \%MMA tend to decrease. Conversely, the null variant had no significance. For GSTM1 gene, the relationship among the active variant and the metabolites and the total urinary arsenic concentration had no significance (Figure 3C), while in the null variant carrying people, \%DMA and \%MMA were higher and decreased proportionally with the increase in total urinary arsenic (Figure 3D). In relation to the As3MT gene, the wild-type genotype showed a decreasing trend for urinary \%DMA and \%MMA, as well as total urinary arsenic increase. The heterozygous/homozygous genotypes had no significant association either with total urinary arsenic concentration or metabolites (Figure 4B).

The results from the multivariate logistic regression analyses are presented in Table 4 . The analysis of the influence of polymorphic variants and potential confounders on InAs, MMA and DMA, adjusted by interaction term showed three statistically significant final models. In the final model for $\%$ MMA (cat. $10-20 \%=$ normal, $>20 \%=$ high) the result was statistically significant $\left(R^{2}=0.40\right.$; likelihood-ratio test, $p<0.01$ ). The gene-gene interactions (As3MT-GSTM1), gene-demographic factors (As3MT-Age) and gene-habits (As3MT-Alcohol consumption), generated larger $\beta$ coefficients and a moderate determination coefficient for \%MMA. In the final model for \%DMA (cat. $60-80 \%=$ normal, $<60 \%=$ low $)$ the result was statistically significant $\left(\mathrm{R}^{2}=0.20\right.$; likelihood-ratio test, $\left.p<0.01\right)$. The gene-gene interactions (GSTO2-GSTP1), and gene-environmental factors (GSTO2-LADD and GSTP1-LADD), generating lower $\beta$ coefficients and a determination not large coefficient. On the other hand, the effect of interactions term in the final model for \%InAs was not relevant and had poor statistical strength was obtained.

Table 4. Multivariate analyses of polymorphic variants on relative urinary arsenic metabolites, adjusted by covariates.

\begin{tabular}{|c|c|c|c|c|c|}
\hline Urinary Arsenic Species & $\beta$ & $\mathrm{SE}^{\mathrm{a}}$ & $p$ Value & $R^{2}$ & $p>$ chi $^{2}$ \\
\hline MMA $^{\text {b }}$ (cat. $0=$ normal, $1=$ high) & & & & 0.40 & $<0.001$ * \\
\hline As3MT ${ }^{c}(T G+$ GG vs. TT $)$ & 15.8 & 5.9 & $0.007 *$ & & \\
\hline GSTM1 d (Active vs. null) & 3.4 & 0.90 & $0.01 *$ & & \\
\hline Age $^{\mathrm{e}}($ cat. $0=18-59,1=>60)$ & 0.86 & 0.69 & 0.21 & & \\
\hline $\mathrm{BMI}^{\mathrm{f}}$ (cat. $0=$ low, $1=$ high) & -1.2 & 0.39 & $0.04 *$ & & \\
\hline Alcohol consumption $(0=$ no, $1=$ yes $)$ & 1.6 & 1.3 & 0.22 & & \\
\hline LADD $^{g}$ (cat. $0=$ low, $1=$ high) & 2.9 & 0.9 & $0.001 *$ & & \\
\hline As3MT-GSTM1 (interaction 1) & 2.3 & 0.95 & $0.01 *$ & & \\
\hline As3MT-Age (interaction 2) & -3.9 & 1.4 & $0.006 *$ & & \\
\hline As3MT-BMI (interaction 3) & -1.9 & 1.6 & 0.23 & & \\
\hline As3MT-Alcohol (interaction 4) & 4.7 & 2.0 & 0.01 * & & \\
\hline DMA $^{\mathrm{h}}($ cat. $0=$ normal, $1=$ low) & & & & 0.20 & $<0.001^{*}$ \\
\hline $\mathrm{GSTO}^{\mathrm{i}}(\mathrm{TC}+\mathrm{CC}$ vs TT $)$ & 2.7 & 1.03 & $0.009 *$ & & \\
\hline GSTP1 ${ }^{\mathrm{j}}(\mathrm{AG}+\mathrm{GG}$ vs. AA $)$ & 1.1 & 0.53 & 0.05 & & \\
\hline GSTM1 d (Active vs. null) & -1.07 & 0.49 & 0.03 * & & \\
\hline $\operatorname{Age}^{\mathrm{e}}($ cat. $0=18-59,1=>60)$ & -1.39 & 0.73 & 0.05 & & \\
\hline LADD $^{\mathrm{g}}$ (cat. $0=$ low, $1=$ high) & -0.56 & 0.62 & 0.36 & & \\
\hline GSTO2-GSTP1 (interaction 1) & -2.3 & 1.06 & $0.03 *$ & & \\
\hline GSTO2-GSTM1 (interaction 2) & 1.92 & 1.08 & 0.07 & & \\
\hline GSTO2-LADD (interaction 3) & -2.1 & 1.02 & $0.04 *$ & & \\
\hline GSTP1-LADD (interaction 4) & 2.1 & 0.99 & $0.03 *$ & & \\
\hline InAs ${ }^{\mathrm{k}}$ (cat. $0=$ normal, $1=$ high) & & & & 0.09 & $0.04 *$ \\
\hline GSTP1 ${ }^{j}(A G+G G$ vs. AA) & 0.74 & 0.38 & 0.05 & & \\
\hline GSTT1 ${ }^{1}$ (Active vs. null) & 0.54 & 0.40 & 0.17 & & \\
\hline As $3 M T^{c}(\mathrm{TG}+\mathrm{GG}$ vs. TT) & -1.6 & 1.1 & 0.14 & & \\
\hline LADD $^{g}$ (cat. $0=$ low, $1=$ high) & -0.54 & 0.41 & 0.19 & & \\
\hline GSTP1-GSTT1 (interaction 1) & 1.5 & 1.2 & 0.21 & & \\
\hline As3MT-LADD (interaction 2) & -0.93 & 0.54 & 0.08 & & \\
\hline
\end{tabular}

Note: ${ }^{*}$ likelihood-ratio test logistic regression $(p<0.05) .{ }^{\text {a }} \mathrm{SE}=$ Standard error. ${ }^{\mathrm{b}}$ Monomethylarsonic acid dichotomized. ${ }^{\mathrm{c}}$ Dominant model for As3MT. ${ }^{\mathrm{d}}$ Basic model for GSTM1. ${ }^{\mathrm{e}}$ Age, dichotomized. ${ }^{\mathrm{f}}$ Body mass index, dichotomized. ${ }^{\mathrm{g}}$ Lifetime average daily dose exposure to arsenic (LADD), dichotomized. ${ }^{\mathrm{h}}$ Dimethylarsinic acid, dichotomized. ${ }^{\mathrm{i}}$ Dominant model for GSTO2. ${ }^{\mathrm{j}}$ Dominant model for GSTP1. ${ }^{\mathrm{k}}$ Inorganic arsenic dichotomized. ${ }^{1}$ Basic model for GSTT1. 


\section{Discussion}

This study gives additional support regarding the role of single nucleotide polymorphisms (SNPs) on arsenic metabolism and body burden. To interpret the findings of the polymorphisms associated with urinary arsenic metabolites, in the present study the interactions between the three arsenic species (\%InAs, \%MMA, and \%DMA), allowed to distinguish between higher or lower \%DMA to the other two species, which could have a biological to the interpretation of "fast secondary methylation step". Similarly, we evaluated higher or lower \%InAs in relation to \%MMA and \%DMA. This analysis could have a biological interpretation of "fast primary methylation step". Several authors have proposed the use of excretion ratios of MMA/InAs and DMA/MMA in the urine, also referred as primary methylation index (PMI) and secondary methylated index (SMI), respectively and used as surrogate biomarkers of the arsenic metabolic capacity [18,38-40]. Nevertheless, SMI and PMI measurements only use information about two of the three species and completely fail to account for the dependence between the arsenic species outcomes which does not have a clear biological interpretation [41,42]. In the present study we fitted a Dirichlet regression on genotype adjusted for genome wide markers, which might be a good way to describe changes in the urinary arsenic metabolites.

Our findings indicated that for people carrying heterozygous/homozygous genotypes of As3MT ( $r$ 3740400), the \%MMA was higher compared to the wild-type genotype. These results are similar to reported in European [18,43], Asian [15,44] and Latin American populations [39,45]. For GSTP1(rs1695), the \%DMA was lower compared to the wild-type genotype. These finding are consistent with the data found in Chilean individuals [31] and contrary to reports in Vietnamese and North American populations [30,46]. Likewise, the deletions such as GSTM1, the \%DMA, \%MMA and \%InAs were higher in the group with null genotype compared to the active genotype. In Chilean population similar data were found for \%MMA and \%InAs, but no for DMA [31]. In this population there is not clear association between GSTM1 gene and the arsenic metabolite excretion levels was found [2]. The focus of these differences may be the direct or indirect relationship that these genes have with the degree of methylation of urinary arsenic species. One of the current hypothesis of the arsenic methylation efficiency in the toxicity of arsenic supposes that a lower excretion of DMA is the result of a decreasing in the degree of methylation of the inorganic forms, generating a minor individual metabolic capacity of arsenic [34,47]. Methylated species of arsenic are recognized to be less toxic than inorganic ones, the methylation has been considered to be a detoxification mechanism for arsenic in the mammals [12]. Although reports in Chilean populations are opposed to the plausibility of this hypothesis, these inconsistent findings need major evidence [48]. Therefore, our results are probably plausible from this first hypothesis, because As3MT and GSTO2 enzymes are related directly with the methylation of inorganic arsenic species, both oxidative and reductive metabolic pathways of As ${ }^{\mathrm{III}}$. As3MT ( $r$ 3740400) genotype is recognized for its importance in the enzymatic expression of As3MT to methylate As ${ }^{\mathrm{III}}$ in species MMA ${ }^{\mathrm{III}}$ and DMA ${ }^{\mathrm{III}}[6,49]$ and the enzymes of GSTO2 (rs156697) genotype could reduce the methylated species $\mathrm{MMA}^{\mathrm{V}}$ and $\mathrm{DMA}^{\mathrm{V}}$ [26]. Although in our study GSTO2 polymorphism (rs156697) did not show statistical significance with any of the urinary arsenic metabolites. In the present study, DMA was the major arsenic metabolite excreted after exposure to arsenic via drinking water, followed by InAs, and MMA. These metabolites have been typically reported in the literature as excretion ratios in ranges of $60-80 \%, 10-30 \%, 10-20 \%$ for DMA, MMA and InAs, respectively [50-52]. However, these may be variable between individuals and populations, particularly DMA, considered the dominant methylated arsenic species in urine samples $[53,54]$. Although, several authors also have reported different values for DMA [41], currently there is no consensus on the urinary excretion percentages to be considered as guiding parameters of arsenic toxicity at the individual level. Similar conclusions have been estimated for MMA [55,56].

Besides, GSTP1, GSTT1 and GSTM1 enzymes participate in detoxification of arsenic but not directly methylating the inorganic arsenic [28]. GSTP1 heterozygous/homozygous variants showed a lower concentration of urinary of InAs compared to the wild-type genotype. Heterozygous genotype of GSTP1 (AG) could have a lower reduction capacity from $\mathrm{As}^{\mathrm{V}}$ to $\mathrm{As}^{\mathrm{III}}$, contributing to $\mathrm{MMA}^{\mathrm{V}}$ 
metabolism [30]. As consequence of low activity of the GST variants, it is possible decrease the detoxification function of GSH, altering the excretion of urinary arsenic metabolites [27]. Besides, GSTM1 may facilitate the methylation of inorganic arsenic. Thus, people with null variants of GSTM1 could not efficiently methylated As ${ }^{\mathrm{III}}$ giving rise to an increase in the amount of urinary inorganic arsenic, and also to an increase in the \%MMA. It has been suggested that the increased excretion of MMA indicates that the second methylation step is inhibited by two hypotheses: excess of inorganic arsenic or the saturation of the enzymatic conversion of MMA to DMA [56]. Interestingly, the relation among the urinary arsenic metabolites and the total urinary arsenic concentration in the present study was evidenced to \%DMA with a trend to increase proportionally with the increase of total urinary arsenic. Moreover, MMA presented a trend to decrease proportionally with the increase of total urinary arsenic. In the first case, there could be an influence of GSTO2 and As3MT homozygous/heterozygous genotypes and in the second case by GSTP1 homozygous/heterozygous genotypes and GSTT1 and GSTM1-null variants. Regarding to the prevalence of GST polymorphisms, GSTT1 and GSTM1 null variants were similar to those reported for other Latin-American studies [2,31]. GSTP1 (rs16959) heterozygous and homozygous genotypes have been also reported with a high prevalence in populations from different countries [46,57]. Likewise, GSTO2(rs156697) polymorphic variants have been evaluated in some US [46] and Poland [18] studies and the prevalence are higher. Furthermore, As3MT (rs3740400) heterozygous and homozygous genotypes have been described with similar prevalence to those reported in the present study [22].

The effects of toxicity of inorganic arsenic may be accelerated with an increase on arsenic exposure dosage [58]. The limited methylation capacity associated with an increased dosage by excessive InAs could be explained through the inhibition of the second methylation step [59,60]. In our study, the concentration of arsenic methylated species followed the trend to increase in subjects exposed to major dosage. There is no evidence suggesting a saturation in the arsenic metabolic capacity, therefore, other explanatory mechanisms including genetic and environmental factors may be possible [18]. Lifetime average daily dose have been reported as an important human risk tool for exposure assessment to many pollutants [61]. In the present study, lifetime average daily dose in exposed subjects to arsenic was slightly higher to the reference dose $(0.3 \mu \mathrm{g} / \mathrm{kg} \mathrm{bw} /$ day $)$. This may explain the risk generated by exposure to water consumption with high concentrations of arsenic, which could show adverse health effects after $>20$ years continuous exposure (cardiovascular disease, hypertension, neurological diseases, respiratory diseases, atherosclerosis, cardiometabolic diseases and several kind of cancers) [62-67].

To explain the influence of these polymorphisms and covariates on urinary arsenic metabolites, the multivariate analyses to \%MMA showed significant associations between As3MT, GSTM1, age, BMI and alcohol consumption. The final models were adjusted by interactions (gene-gene, gene-physical factors and gene-habits) explaining $40 \%$ of the variation $\left(R^{2}=0.40 ; p<0.001\right)$. As As3MT and GSTM1 polymorphic variants have effects on MMA in the same pathway, their interaction may increase the strength of the association in the final model. Moreover, in the scientific literature have been reported interactions among GSTP1 variant and GSTM1-null, resulted in significantly reduced GST enzymatic activity [28], which could affect arsenic metabolism [29,46]. Nevertheless, for As3MT and GSTM1 no findings were obtained, therefore more consistent evidence is needed. Covariates tested as potential confounders, their interactions were analyzed including As3MT-age and As3MT-alcohol consumption to explain changes in MMA urinary excretion. Recent reports have suggested that age of subjects is related with methylation capacity [48]. Adults $\geq 63$ may have significantly lower urinary excretions of DMA but higher those of InAs compared with young subjects [68]. Due to these contradictory findings and that aging can probably be associated with a variety of functional changes in the organs involved in the metabolism or retention of the metabolites of arsenic, their effect on arsenic metabolism needs to be confirmed [38]. On the other hand, in this work the alcohol consumption showed significant association with MMA and its interaction with As3MT enhance its effects. In relation to that, some authors suggest as a potential mechanism that the presence of GST polymorphic genes could alter the capacity 
to conjugate lipid peroxidation products, cytotoxic compounds, and free radicals generated during alcohol metabolism is reduced [69,70]. Other authors observed a relationship among As3MT alleles, high arsenic level and the presence of glutathione (GSH) in the reaction medium. These authors suggested that individual variations in the GSH metabolism should also be included among the modifiers of arsenic metabolism in humans [25,30,71].

Limitations of this study are related to the non-measurement of other potential routes of arsenic exposure such as agriculture, mining and landfills, which can be sources of occupational arsenic exposure. Likewise, although the forms of organic arsenic were not measured in our study, when we compared the total urinary arsenic concentration with the total sum of urinary arsenic metabolites, the median was very similar. These small differences could be due to other organic arsenic species, such as arsenobetaine (AsB) (abundant in crustacean seafood) increasing the total urinary arsenic concentration and excreted unchanged into the urine [38,72]. Therefore, this organic arsenic form appears to not influence DMA concentration. Whereby the urinary metabolites found in this study are not related to seafood consumption. Besides, other covariates were evaluated through surveys with which we could not exclude the possibility of an information bias. Nevertheless, strengths of the study included assessing the influence of genetic polymorphisms and their interactions to arsenic metabolism will provide abundant epidemiological data to health institutions. This will allow the understanding of the individual and population differences to identify susceptible groups in Colombia, making better risk estimates of adverse effects to arsenic from drinking groundwater intake. With this information, a readjustment of strategic planning in public health could be achieved in the case of contamination of drinking water in high-risk populations. Nonetheless, to obtain greater power and statistical strength with estimates and predictions about arsenic metabolism, it is necessary to evaluate the interactions among different isoforms of other genes associated with potential factors involved in the process, which could improve the usefulness of the results obtained.

\section{Materials and Methods}

\subsection{Subject of Study and Sample}

This study was conducted from September of 2017 to December of 2018 and included 151 adults aged between 18 and 81 years old selected from the municipalities of Margarita and San Fernando, in Bolivar department, Colombia. Margarita $\left(9^{\circ} 09^{\prime} 11^{\prime \prime} \mathrm{N} 74^{\circ} 17^{\prime} 17^{\prime \prime} \mathrm{W}\right)$ is located at an altitude of $20 \mathrm{~m}$ asl with average of temperature of $28{ }^{\circ} \mathrm{C}$, extension of $295 \mathrm{Km}^{2}$ and a population of 9876 inhabitants, about $90 \%$ of them living in the rural areas. San Fernando $\left(9^{\circ} 12^{\prime} 43^{\prime \prime} \mathrm{N} 74^{\circ} 19^{\prime} 23^{\prime \prime} \mathrm{W}\right)$ is located at an altitude of $33 \mathrm{~m}$ asl with average of temperature of $27.8^{\circ} \mathrm{C}$, extension of $288 \mathrm{Km}^{2}$ and a population of 13,753 inhabitants, about of $80 \%$ of them living in the rural areas (Figure S1). Eligible participants enrolled in this study have been living in these municipalities for at least 5 years and consume groundwater on a regular basis. Exclusion criteria were as follows: occupational exposure to arsenic, medical history of renal or hepatic disease, exposure to drug therapy within the two months before sampling, consumption of seafood within $48 \mathrm{~h}$ before sampling [53], and a family relationship to another study subject. This study was approved by the Human Research Ethical Committee of the University of Cartagena, Colombia (25 May 2017) and was registered on the University of Cartagena Register (\#403962017, 2 June 2017).

The sample size was determined based on a type I error of $5 \%$ and power of $80 \%$. Based on previous data, using Stata ${ }^{\circledR}$ software (V12, Stata Corp. LP, College Station, TX, USA); the lowest expected frequency for heterozygous and/or homozygous variants (GSTP1) was used [8]. Besides, it was included the lowest expected frequency of all the urinary arsenic species percentages (MMA $=18.3 \%$ ) [8], resulted in a target sample size of 140 subjects. To account for possible damage to blood specimens for DNA testing or incomplete processing of the questionnaire, the sample size was increasing $10 \%$ (14 subjects). Thus, a total of 154 donors were recruited, 3 subjects were excluded because they did not fulfill the parameters previously cited. Therefore, the final population consisted of 151 participants. 
A survey was used to assess the demographic and anthropometric information about study participants, including lifestyle and smoking history. Information regarding the smoking habits and alcohol consumption was obtained through a self-administered questionnaire, with a supplementary interview. Subjects were asked whether they were lifelong nonsmokers or current smokers. We use the Brinkman's index of tobacco addiction [73] to generate two groups related to smoking: nonsmoker and smoker group. Similarly, to evaluate alcohol consumption, we used a cut-off value at least $280 \mathrm{~g}$ per week [74].

\subsection{Sample Collections}

\subsubsection{Groundwater Collection}

Twenty-two randomly selected groundwater wells sites were selected in the Margarita and San Fernando municipalities (Figure S1). Water samples were collected in $250 \mathrm{~mL}$ polyethylene bottles, previously treated with $10 \% \mathrm{HNO}_{3}$ for $2 \mathrm{~h}$, rinsed with ultra-pure water $(18 \mathrm{M} \Omega \cdot \mathrm{cm}$; distilled and deionized water) and dried (to avoid heavy metal contamination). Containers were also rinsed, 3 times with the same sampling water, before taking. After sample collection, they were kept under refrigeration, transported, and stored at the laboratory, until analyzed.

\subsubsection{Urine Collection}

Urine samples from study participants were collected in $25 \mathrm{~mL}$ polyethylene bottles, previously treated with $10 \% \mathrm{HNO}_{3}$ for $2 \mathrm{~h}$, and rinsed with ultra-pure water. The urine collection of each subject was a spot sample in the morning as the first one. To reduce variation of the arsenic concentrations among individuals, those were adjusted by creatinine. Samples were kept under refrigeration, transported at the laboratory and then lyophilized immediately (FreeZon 4.5 Liter Benchtop Freeze Dry System) to avoid possible oxidation of inorganic arsenic species. The samples were reconstituted with $1.8 \mathrm{~mL}$ ultra-pure water in Eppendorf tubes and filtered using PTFE syringe filters $(0.45 \mu \mathrm{m})$ (Whatman, GE Healthcare Life Sciences, UK) which analyzed immediately.

\subsubsection{Blood Samples Collection}

Peripheral blood samples from study participants were collected by venous puncture using lead-free vacutainer tubes containing EDTA as an anticoagulant (Becton Dickinson, Inc., Rutherford, NJ, USA). These were collected from all the participants at the time of enrollment and were transported at the laboratory until analysis. Genomic DNA was extracted through the High Pure PCR Template Preparation Kit (catalog number 11796828001; Roche Diagnostics GmbH, Mannheim, Germany).

\subsection{Groundwater Quality and Arsenic Determination}

Various physicochemical water quality parameters were measured with the appropriate instruments. These parameters included turbidity, $\mathrm{pH}$, conductivity, temperature, dissolved oxygen, chloride, fluoride, nitrite, nitrate, magnesium and others. Sample measurements were determined in situ using a turbidimeter HI83414 (Hanna instruments) for Turbidity (NTU) and a portable $\mathrm{pH} / \mathrm{ISE} / \mathrm{Conductivity/RDO/DO/Temperature} \mathrm{Multiparameter} \mathrm{Meter} \mathrm{(Thermo} \mathrm{Scientific} \mathrm{Orion} \mathrm{Star}$ A329) for conductivity $(\Omega / \mathrm{cm}), \mathrm{pH}$, temperature $\left({ }^{\circ} \mathrm{C}\right)$, and Dissolved Oxygen $(\mathrm{mg} / \mathrm{L})$. Chloride $(\mathrm{mg} / \mathrm{L})$ and fluoride $(\mathrm{mg} / \mathrm{L})$ were measured in the laboratory using a benchtop multiparameter $\mathrm{pH} / \mathrm{ISE}$ (Thermo Scientific Orion 4-Start Plus) with the respective ion selective electrodes. Nitrite $(\mathrm{mg} / \mathrm{L})$, nitrate $(\mathrm{mg} / \mathrm{L})$ were measured by colorimetry using a spectrophotometer Genesys 10S UV-VIS (Thermo Scientific). Total dissolved solid (mg/L), alkalinity ( $\mathrm{mg} / \mathrm{L})$, total hardness $(\mathrm{mg})$, calcium $(\mathrm{mg} / \mathrm{L})$, and magnesium $(\mathrm{mg} / \mathrm{L})$ were determined followed the standard method, American Public Health Association (APHA), American Water Works Association (AWWA) and World Economic Forum (WEF). Total arsenic (TAs) concentrations in groundwater samples were digested with $\mathrm{HNO}_{3}$ and $\mathrm{HClO}_{4}$. Then it was measured by Hydride Generation-Atomic Absorption Spectrometer (HG-AAS) equipped with a VP-100 
continuous flow vapor generator system (Thermo Scientific iCE 3500). The speciation analysis for inorganic arsenic species (arsenite and arsenate) in duplicated groundwater samples was performed by a High-Performance Liquid Chromatography (HPLC) coupled to Hydride Generation-Atomic Fluorescence Spectrometry (HG-AFS); PSA 10.055 Millennium Excalibur system (PS Analytical Ltd., Orpington, Kent, UK).

\subsection{Exposure/Risk Assessment}

Human exposure to arsenic in groundwater was calculated using the lifetime average daily dose (LADD) which is the amount of daily arsenic exposed from one or more sources and is expressed on the basis of $\mu \mathrm{g}$ of arsenic per $\mathrm{kg}$ body weight per day ( $\mu \mathrm{g} / \mathrm{kg} \mathrm{bw} /$ day), according the following equation:

$$
\mathrm{LADD}=(\mathrm{C} \times \mathrm{IR} \times \mathrm{ED} \times \mathrm{EF}) /(\mathrm{BW} \times \mathrm{AT})
$$

where $C$ is arsenic concentration in water $(\mu \mathrm{g} / \mathrm{L}), \mathrm{IR}$ is the water intake rate per day (L/day), ED is exposure duration (years), EF is the exposure frequency (days/year), BW is the body weight $(\mathrm{Kg})$, and AT is the average time (day). From there the hazard quotient $(\mathrm{HQ})$ was determined as follows:

$$
\mathrm{HQ}=\mathrm{LADD} / \mathrm{RfD}
$$

The RfD (reference dose) for arsenic is $0.3 \mu \mathrm{g} / \mathrm{kg}$ bw/day from U.S. Environmental Protection Agency (US EPA), for non-cancer outcome such as hyperpigmentation, keratosis and possible vascular complications [75]. Results of HQ above 1, indicate an increased risk of adverse health effects.

\subsection{Instrumental Analysis for Urinary Arsenic Speciation}

Urinary arsenic species (As ${ }^{\mathrm{III}}, \mathrm{As}^{\mathrm{V}}, \mathrm{MMA}$ and DMA) were determined using HPLC-HG-AFS [76,77]. Urine samples were eluted using a Hamilton PRP-X100 anion-exchange column of $250 \mathrm{~mm} \times 4.1$ i.d., particle size $10 \mu \mathrm{m}$ (Hamilton Company, Reno, NV, USA) with $\mathrm{KH}_{2} \mathrm{PO}_{4} / \mathrm{K}_{2} \mathrm{HPO}_{4}$ aqueous buffer as mobile phase ( $\mathrm{pH} 5.8$ ), a flow rate of $1.0 \mathrm{~mL} / \mathrm{min}$. For total urinary arsenic (TuAs) determination, samples were digested with $\mathrm{HNO}_{3}$ and $\mathrm{HClO}_{4}$ to convert the arsenic species to inorganic ones and then these were measured by HG-AFS.

\subsection{Quality Assurance/Quality Control.}

We used the blank procedure to determine the limit of detection (LOD) and limit of quantification (LOQ) of the method for total arsenic in water obtaining values of $0.7 \mu \mathrm{g} / \mathrm{L}$ and $1.2 \mu \mathrm{g} / \mathrm{L}$, respectively. Six-point standard calibration curves were used to quantify the sample concentrations from peak areas and the regression coefficients were above of 0.995 . Urinary arsenic species concentrations were analyzed as $\mathrm{As}^{\mathrm{III}}, \mathrm{As}^{\mathrm{V}}, \mathrm{MMA}$ and DMA. Also, InAs was the sum of inorganic species $\left(\mathrm{As}^{\mathrm{III}}+\mathrm{As}^{\mathrm{V}}\right)$. Seronorm ${ }^{\mathrm{TM}}$ Trace Elements Urine was used as an accuracy control for the analyses (reported $106 \pm 2 \mu \mathrm{g} / \mathrm{L}$ of total As) (Seronorm Pharmaca, Billingstad, Norway) to check the recovery of arsenic species by HPLC-HG-AFS, obtaining a sum of $107.8 \pm 2.4 \mu \mathrm{g} / \mathrm{L}$, which corresponded to $99.5 \pm 2.1 \mu \mathrm{g} / \mathrm{L}$ of $A s^{\mathrm{V}}$ and $8.3 \pm 0.3 \mu \mathrm{g} / \mathrm{L}$ of DMA. Limits of detection (LOD) for urinary arsenic species were as the follow: $\mathrm{As}^{\mathrm{III}}=0.17, \mathrm{As}^{\mathrm{V}}=0.38, \mathrm{MMA}=0.30$ and $\mathrm{DMA}=0.45 \mu \mathrm{g} / \mathrm{L}$. Urinary arsenic concentrations were adjusted by dilution to eliminate variation from fluid balance. Therefore, urinary creatinine was determined by spectrophotometer Genesys 10S UV-VIS (Thermo Scientific, USA) and urinary total arsenic concentrations were expressed as $\mu \mathrm{g}$ As per g creatinine.

\subsection{Genotyping Polymorphisms}

Genomic DNA was isolated from peripheral blood samples through the High Pure PCR Template Preparation Kit (catalog number 11796828001; Roche Diagnostics GmbH, Mannheim, Germany). DNA samples were quantified at 260/280 nm using a nanodrop spectrophotometer (model DS-11, 
FX Series Spectrophotometer, USA). Deletions (GSTT1-null, and GSTM1-null) were determined by direct PCR and total absence or presence of $G S T T 1^{*} 0$ and $G S T M 1{ }^{*} 0$ gene was determined in a G-Storm Thermocycler (model GS00482, IDT Fermelo-Biotec, Chile). Beta Globin and Cytochrome P4501A1 were used as an internal positive amplification control for GSTT1 and GSTM1, respectively [78]. Heterozygous and homozygous non-null individuals could not be differentiated; therefore, null genotypes reported elsewhere are actually double null genotypes. The charging procedure of the amplification products was used by electrophoresis $(80 \mathrm{~V}, 2 \mathrm{~h}$ ) on a $4 \%$ agarose gel (Bio-Rad Lab., Richmond, CA, USA) and detected by Syber Safe DNA (Invitrogen ${ }^{\circledR}$ ), staining under an ultraviolet illuminator, and photographed. The substitutions (GSTP1-rs1695; Assay ID:C_3237198_20, GSTO2-rs156697; Assay ID:C_3223136_1 and As3MT-rs3740400; Assay ID:C_27510174_10) were evaluated by Real-Time PCR (RT-PCR), using TaqMan ${ }^{\circledR}$ Genotyping Assays (Thermo Fishier Scientific Inc. ${ }^{\circledR} ;$ C. Number: 4351379 and 4362691) in a Stratagene ${ }^{\circledR}$ Mx3000P Real-Time PCR system (Agilent Technologies, Waldbronn, Alemania). The context sequences for TaqMan ${ }^{\circledR}$ probes and primers for PCR are listed in Table S1 and the PCR conditions for the five genes are detailed in Table S2. The reference sequence of each gene was based on GenBank sequences at NCBI (https://www.ncbi.nlm.nih.gov/genbank). For quality assurance purposes, we randomly choose a $20 \%$ of the samples for (a) repetition of the analysis and (b) PCR and Restriction fragment length polymorphism (RFLP) analysis for coincidence for RT-PCR analyzed samples or c) confirmation by sequencing (ABI Prism 3100 Genetic Analyzer), when the PCR and RFLP and RT-PCR analyses were not coincident.

\subsection{Statistical Analyses}

Kolmogorov-Smirnov's one sample test was used to check for normal distribution of data for each variable. Because concentrations of arsenic in groundwater and urinary arsenic species did not have a normal distribution, hence the estimation of their medians and interquartile ranges were used to statistical description. Deviation of Hardy-Weinberg equilibrium (HWE) was used for a quality control measurement, GSTP1-rs1695, GSTO2-rs156697 and As3MT- rs3740400 genotype distributions were tested using the chi-square $\chi^{2}$-test $(p>0.05)$. Genotype frequencies were calculated as the proportion of individuals with a given genotype by dividing into the total number of participants and the allelic frequencies were calculated as the frequencies of heterozygous and homozygous alleles by dividing into the total allelic varieties. The study population was divided into two subgroups for purpose of analysis: participants with low-exposure doses (LADD $\leq 0.3 \mu \mathrm{g} / \mathrm{kg}$ bw/day) made up one group and those with high-exposure doses (LADD $>0.3 \mu \mathrm{g} / \mathrm{kg} \mathrm{bw} /$ day) forming the second group. Pairwise comparisons were performed between low and high exposure dose, using parametric and nonparametric tests (Wilcoxon rank sum test, $\chi^{2}$-test, $t$-test). For multiple comparisons by genotypes Bonferroni correction was used. A complementary analysis to understand the magnitude. To understand the significance differences between low and high exposure, effect size test was performed [79]. To analyze the polymorphism influence on urinary arsenic excretion metabolites, Dirichlet regression and Logistic regression multivariate were used. The urinary arsenic species were incorporated in the analysis as dependent variables while the polymorphisms and LADD were incorporated as independent variables. Interaction terms among the main genotypes that provided a $p$-value $<0.2$ through of genetic dominant models (wild-type vs heterozygous + homozygous genotype) and potential confounders (age, BMI, smoking history and lifestyle) were taken into account. Dominant models over additive model are considered on study population with a better biological sense. The urinary arsenic species were incorporated in the analysis as dependent variables, the polymorphisms and LADD as independent variables. The multicollinearity of independent variables was assessed calculating of variance inflation factor (VIF). The statistical analyses and geospatial data (study site map in the Figure S1) were performed using R software environment [80]. 


\section{Conclusions}

The gene-gene interactions between polymorphisms As3MT*GSTM1 and GSTO2*GSTP1 could be potential modifiers of urinary arsenic metabolites, increasing MMA and decreasing DMA. Additionally, synergistic effect among these polymorphisms and age, LADD of arsenic and alcohol consumption might vary the arsenic individual metabolic capacity a large part. This is an important issue to consider, particularly in this Colombian study population from where the inhabitants are exposed to arsenic in from groundwater water supply.

Supplementary Materials: Supplementary materials can be found at http://www.mdpi.com/1422-0067/21/14/ 4832/s1.

Author Contributions: Conceptualization, F.G.-M. and B.J.-R.; Methodology, F.G.-M., L.A.Q., D.S.-R. and B.J.-R.; Validation, F.G.-M., L.A.Q., D.S.-R. and B.J.-R.; Formal Analysis, F.G.-M. and B.J.-R.; Investigation, F.G.-M., C.A.S. and N.M.V.; Resources, D.S.-R., L.A.Q., F.G.-M. and B.J.-R.; Data Curation, F.G.-M. and B.J.-R.; Writing-Original Draft Preparation, F.G.-M.; Writing_Review \& Editing, L.A.Q., N.M.V., D.S.-R. and B.J.-R.; Visualization, L.A.Q., D.S.-R. and B.J.-R.; Supervision, B.J.-R.; Project Administration, F.G.-M.; Funding Acquisition, F.G.-M. and B.J.-R. All authors have read and agreed to the published version of the manuscript.

Funding: This research was funded by Ministerio de Ciencia, Tecnología e Innovación (MinCiencias) in Colombia: 110777757778.

Acknowledgments: We wish to thank Matias Martínez from CQF, University of Chile and Sindy Mendoza from GQYMA, University of Cartagena. This research was supported by Ministerio de Ciencia, Tecnología e Innovación (MinCiencias) in Colombia (Grant No. 110777757778).

Conflicts of Interest: The authors declare no conflict of interest.

\section{References}

1. Caceres, D.D.; Pino, P.; Montesinos, N.; Atalah, E.; Amigo, H.; Loomis, D. Exposure to inorganic arsenic in drinking water and total urinary arsenic concentration in a Chilean population. Environ. Res. 2005, 98, 151-159. [CrossRef]

2. Caceres, D.D.; Werlinger, F.; Orellana, M.; Jara, M.; Rocha, R.; Alvarado, S.; Quiñones, L. Polymorphism of Glutathione S-Transferase (GST) variants and its effect on distribution of urinary arsenic species in people exposed to low inorganic arsenic in tap water: An exploratory study. Arch. Environ. Occup. Health 2010, 65, 140-147. [CrossRef]

3. Sun, H.J.; Rathinasabapathi, B.; Wu, B.; Luo, J.; Pu, L.P.; Ma, L.Q. Arsenic and selenium toxicity and their interactive effects in humans. Environ. Int. 2014, 69, 148-158. [CrossRef]

4. IARC (International Agency for Research on Cancer). Some drinking-water disinfectants and contaminants, including arsenic, IARC. Monogr. Eval. Carcinog. Risks Hum. 2004, 84, 1-477.

5. WHO (World Health Organization). Arsenic in Drinking-water: Background document for development of WHO Guidelines for Drinking-water Quality; WHO Press, World Health Organization: Geneva, Switzerland, 2011.

6. Engström, K.S.; Broberg, K.; Concha, G.; Nermell, B.; Warholm, M.; Vahter, M. Genetic Polymorphisms Influencing Arsenic Metabolism: Evidence from Argentina. Environ. Health Perspect. 2007, 115, $599-605$. [CrossRef]

7. Bundschuh, J.; Litter, M.I.; Parvez, F.; Roman-Ross, G.; Nicolli, H.B.; Jean, J.S.; Liu, C.W.; Lopez, D.; Armienta, M.A.; Guilherme, L.R.; et al. One century of arsenic exposure in Latin America: A review of history and occurrence from 14 countries. Sci. Total Environ. 2012, 429, 2-35. [CrossRef] [PubMed]

8. González-Martínez, F.; Sánchez-Rodas, D.; Cáceres, D.; Martínez, M.; Quiñones, L.; Johnson-Restrepo, B. Arsenic exposure, profiles of urinary arsenic species, and polymorphism effects of glutathione-s-transferase and metallothioneins. Chemosphere 2018, 212, 927-936. [CrossRef]

9. Alonso, D.L.; Latorre, S.; Castillo, E.; Brandao, P.F. Environmental occurrence of arsenic in Colombia: A review. Environ. Pollut. 2014, 186, 272-281. [CrossRef] [PubMed]

10. Teixeira, M.C.; Caldeira, A.; Silva, C.; Chakmeng, J. Arsenic contamination assessment in Brazil—Past, present and future concerns: A historical and critical review. Sci. Total Environ. 2020, 730, 138217. [CrossRef] [PubMed]

11. Vahter, M. Mechanisms of arsenic biotransformation. Toxicology 2002, 181, 211-217. [CrossRef] 
12. Tseng, C.H. Arsenic methylation, urinary arsenic metabolites and human diseases: Current perspective. J. Environ. Sci. Health C. Environ. Carcinog. Ecotoxicol. Rev. 2007, 25, 1-22. [CrossRef] [PubMed]

13. Naranmandura, H.; Suzuki, N.; Suzuki, K.T. Trivalent arsenicals are bound to proteins during reductive methylation. Chem. Res. Toxicol. 2006, 19, 1010-1018. [CrossRef] [PubMed]

14. Hayakawa, T.; Kobayashi, Y.; Cui, X.; Hirano, S. A new metabolic pathway of arsenite: Arsenic-glutathione complexes are substrates for human arsenic methyltransferase Cyt19. Arch. Toxicol. 2005, 79, 83-91. [CrossRef] [PubMed]

15. Agusa, T.; Fujihara, J.; Takeshita, H.; Iwata, H. Individual variations in inorganic arsenic metabolism associated with AS3MT genetic polymorphisms. Int. J. Mol. Sci. 2011, 12, 2351-2382. [CrossRef] [PubMed]

16. Lovreglio, P.; D’Errico, M.N.; Gilberti, M.E.; Drago, I.; Basso, A.; Apostoli, P.; Soleo, L. The influence of diet on intra and inter-individual variability of urinary excretion of arsenic species in Italian healthy individuals. Chemosphere 2012, 86, 898-905. [CrossRef] [PubMed]

17. De Chaudhuri, S.; Ghosh, P.; Sarma, N.; Majumdar, P.; Sau, T.J.; Basu, S.; Roychoudhury, S.; Ray, K.; Giri, A.K. Genetic variants associated with arsenic susceptibility: Study of purine nucleoside phosphorylase, arsenic (+3) methyltransferase, and glutathione S-transferase omega genes. Environ. Health Perspect. 2008. [CrossRef]

18. Janasik, B.; Reszka, E.; Stanislawska, M.; Wieczorek, E.; Fendler, W.; Wasowicz, W. Biological monitoring and the influence of genetic polymorphism of As3MT and GSTs on distribution of urinary arsenic species in occupational exposure workers. Int. Arch. Occup. Environ. Health 2015, 88, 807-818. [CrossRef]

19. Antonelli, R.; Shao, K.; Thomas, D.; Sams, R.; Cowden, J. AS3MT, GSTO, and PNP polymorphisms: Impact on arsenic methylation and implications for disease susceptibility. Environ. Res. 2014, 132, 156-167. [CrossRef]

20. Yu, L.; Kalla, K.; Guthrie, E.; Vidrine, A.; Klimecki, W.T. Genetic variation in genes associated with arsenic metabolism: Glutathione S-transferase omega 1-1 and purine nucleoside phosphorylase polymorphisms in European and indigenous Americans. Environ. Health Perspect. 2003, 111, 1421-1427. [CrossRef]

21. Shockley, K.R.; Witmer, D.; Burgess-Herbert, S.L.; Paigen, B.; Churchill, G.A. Effects of atherogenic diet on hepatic gene expression across mouse strains. Physiol. Genom. 2009, 39, 172-182. [CrossRef]

22. Engström, K.; Vahter, M.; Mlakar, S.J.; Concha, G.; Nermell, B.; Ragib, R.; Cardozo, A.; Broberg, K. Polymorphisms in arsenic (+ III oxidation state) methyltransferaze (As3MT) predict gene expression of As3MT as well as arsenic metabolism. Environ. Health Perspect. 2011, 119, 182-188. [CrossRef] [PubMed]

23. Schuliga, M.; Chouchane, S.; Snow, E. Upregulation of Glutathione-Related Genes and Enzyme Activities in Cultured Human Cells by Sublethal Concentrations of Inorganic Arsenic. Toxicol. Sci. 2002, 70, 183-192. [CrossRef] [PubMed]

24. Quiñones, L.; Lee, K.; Varela, F.N.; Escala, M.; García, K.; Godoy, L.; Castro, A.; Soto, J.; Saavedra, I.; Caceres, D. Cancer pharmacogenetics: Study of genetically determined variations on cancer susceptibility due to xenobiotic exposure. Rev. Med. Chil. 2006, 134, 499-515. [CrossRef]

25. McClintock, T.R.; Chen, Y.; Bundschuh, J.; Oliver, J.T.; Navoni, J.; Olmos, V.; Lepori, E.V.; Ahsan, H.; Parvez, F. Arsenic exposure in Latin America: Biomarkers, risk assessments and related health effects. Sci. Total Environ. 2012, 1, 76-91. [CrossRef] [PubMed]

26. Schmuck, E.M.; Board, P.G.; Whitbread, A.K.; Tetlow, N.; Cavanaugh, J.A.; Blackburn, A.C.; Masoumi, A. Characterization of the monomethylarsonate reductase and dehydroascorbate reductase activities of Omega class glutathione transferase variants: Implications for arsenic metabolism and the age-at-onset of Alzheimer's and Parkinson's diseases. Pharm. Genom. 2005, 15, 493-501. [CrossRef] [PubMed]

27. Leslie, E.M.; Haimeur, A.; Waalkes, M.P. Arsenic transport by the human multidrug resistance protein 1 (MRP1/ABCC1). J. Biol. Chem. 2004, 279, 32700-32708. [CrossRef]

28. Zhong, S.; Zhou, S.; Chen, X.; Chan, S.Y.; Chan, E.; Ng, K.; Duan, W.; Huang, M. Relationship between genotype and enzyme activity of S-transferases M1 and P1 in Chinese. Eur. J. Pharm. Sci. 2006, 28, 77-85. [CrossRef]

29. Agusa, T.; Iwata, H.; Fujihara, J.; Kunito, T.; Takeshita, H.; Trang, P.T.; Viet, P.H.; Tanabe, S.; Minh, T.B. Genetic polymorphisms in glutathione S-transferase (GST) superfamily and arsenic metabolism in residents of the Red River Delta, Vietnam. Toxicol. Appl. Pharmacol. 2010, 242, 352-362. [CrossRef]

30. Agusa, T.; Kunito, T.; Tue, N.M.; Lan, V.T.; Fujihara, J.; Takeshita, H.; Minh, T.B.; Trang, P.T.; Takahashi, S.; Hung, V.P.; et al. Individual variations in arsenic metabolism in Vietnamese: The association with arsenic exposure and GSTP1 genetic polymorphism. Metallomics 2012, 4, 9-100. [CrossRef] 
31. Marcos, R.; Martinez, V.; Hernández, A.; Creus, A.; Sekaran, C.; Tokunaga, H.; Quinteros, D. Metabolic profile in workers occupationally exposed to arsenic: Role of GST polymorphisms. J. Occup. Environ. Med. 2006, 48, 334-341. [CrossRef]

32. Wood, T.; Salavagionne, O.; Mukherjee, B.; Wang, L.; Klumpp, A.; Thomae, B.; Eckloff, B.; Schaid, D.; Wieben, E.; Weinshilboum, R. Human arsenic methyltransferase (As3MT) Pharmacogenetics. Gene resequencing and functional genomics studies. J. Biol. Chem. 2006, 281, 7364-7373. [CrossRef] [PubMed]

33. Hsieh, R.L.; Su, C.T.; Shiue, H.S.; Chen, W.J.; Huang, S.R.; Lin, Y.C.; Lin, M.I.; Mu, S.C.; Chen, R.J.; Hsueh, Y.M. Relation of polymorphism of arsenic metabolism genes to arsenic methylation capacity and developmental delay in preschool children in Taiwan. Toxicol. Appl. Pharmacol. 2017, 15, 37-47. [CrossRef] [PubMed]

34. Lin, Y.C.; Chen, W.J.; Huang, C.Y.; Shiue, H.S.; Su, C.T.; Ao, P.L.; Pu, Y.S.; Hsueh, Y.M. Polymorphisms of Arsenic (+3 Oxidation State) Methyltransferase and Arsenic Methylation Capacity Affect the Risk of Bladder Cancer. Toxicol. Sci. 2018, 164, 328-338. [CrossRef]

35. Huang, C.Y.; Lin, Y.C.; Shiue, H.S.; Chen, W.J.; Su, C.T.; Pu, Y.S.; Ao, P.L.; Hsueh, Y.M. Comparison of arsenic methylation capacity and polymorphisms of arsenic methylation genes between bladder cancer and upper tract urothelial carcinoma. Toxicol. Lett. 2018, 295, 64-73. [CrossRef] [PubMed]

36. Gómez-Rubio, P.; Klimentidis, Y.C.; Cantu-Soto, E.; Meza-Montenegro, M.; Billheimer, D.; Lu, Z.; Chen, Z.; Klimecki, W.T. Indigenous American ancestry is associated with arsenic methylation efficiency in an admixed population of northwest Mexico. J. Toxicol. Environ. Health A 2012, 75, 36-49. [CrossRef] [PubMed]

37. Fu, S.; Wu, J.; Li, Y.; Liu, Y.; Gao, Y.; Yao, F.; Qiu, C.; Song, L.; Wu, Y.; Liao, Y.; et al. Urinary arsenic metabolism in a Western Chinese population exposed to high-dose inorganic arsenic in drinking water: Influence of ethnicity and genetic polymorphisms. Toxicol. Appl. Pharm. 2014, 274, 117-123. [CrossRef] [PubMed]

38. Gao, S.; Lin, P.I.; Mostofa, G.; Quamruzzaman, Q.; Rahman, M.; Rahman, M.L.; Su, L.; Hsueh, Y.-M.; Weisskopf, M.; Coull, B.; et al. Determinants of arsenic methylation efficiency and urinary arsenic level in pregnant women in Bangladesh. Environ. Health 2019, 18, 94. [CrossRef] [PubMed]

39. Chung, J.S.; Kalman, D.A.; Moore, L.E.; Kosnett, M.J.; Arroyo, A.P.; Beeris, M.; Mazumder, D.N.; Hernandez, A.L.; Smith, A.H. Family correlations of arsenic methylation patterns in children and parents exposed to high concentrations of arsenic in drinking water. Environ. Health Perspect. 2002, 110, 729-733. [CrossRef]

40. Chen, X.; Guo, X.; He, P.; Nie, J.; Yan, X.; Zhu, J.; Zhang, L.; Mao, G.; Wu, H.; Liu, Z.; et al. Interactive influence of N6AMT1 and As3MT genetic variations on arsenic metabolism in the population of inner Mongolia, China. Toxicol. Sci. 2017, 155, 124-134. [CrossRef]

41. Vahter, M. Genetic polymorphism in the biotransformation of inorganic arsenic and its role in toxicity. Toxicol. Lett. 2000, 112, 209-217. [CrossRef]

42. Loffredo, C.A.; Aposhian, H.V.; Cebrian, M.E.; Yamauchi, H.; Silbergeld, E.K. Variability in human metabolism of arsenic. Environ. Res. 2003, 92, 85-91. [CrossRef]

43. Mandal, B.K.; Ogra, Y.; Susuki, K.T. Identification of dimethylarsinous and monomethylarsonous acids in human urine of the arsenic affected areas in West Bengal India. Chem. Res. Toxicol. 2001, 14, 371-378. [CrossRef] [PubMed]

44. Hsueh, Y.M.; Hsu, M.K.; Chiou, H.Y.; Yang, M.H.; Huang, C.C.; Chen, C.J. Urinary arsenic speciation in subjects with or without restriction from seafood dietary intake. Toxicol. Lett. 2002, 133, 83-91. [CrossRef]

45. Middleton, D.R.; Watts, M.J.; Hamilton, E.M.; Ander, E.L.; Close, R.M.; Exley, K.S.; Crabbe, H.; Leonardi, G.S.; Fletcher, T.; Polya, D.A. Urinary arsenic profiles reveal exposures to inorganic arsenic from private drinking water supplies in Cornwall, UK. Sci. Rep. 2016, 6, 25656. [CrossRef] [PubMed]

46. Vahter, M.; Concha, G.; Nermell, B.; Nilsson, R.; Dulout, F.; Natarajan, A.T. A unique metabolism of inorganic arsenic in native Andean women. Eur. J. Pharm. 1995, 293, 455-462. [CrossRef]

47. Concha, G.; Nermell, B.; Vahter, M. Spatial and temporal variations in arsenic exposure via drinking-water in northern Argentina. J. Health Popul. Nutr. 2006, 24, 317-326. [PubMed]

48. Ramprasath, T.; Murugan, P.S.; Prabakaran, A.D.; Gomathi, P.; Rathinavel, A.; Selvam, G.S. Potential risk modifications of GSTT1, GSTM1 and GSTP1 (glutathione-S-transferases) variants and their association to CAD in patients with type-2 diabetes. Biochem. Biophys. Res. Commun. 2011, 407, 49-53. [CrossRef]

49. Lindberg, A.L.; Ekström, E.C.; Nermell, B.; Rahman, M.; Lonnerdal, B.; Persson, L.A.; Vahter, M. Gender and age differences in the metabolism of inorganic arsenic in a highly exposed population in Bangladesh. Environ. Res. 2008, 106, 110-120. [CrossRef] 
50. Li, L.; Ekström, E.C.; Goessler, W.; Lönnerdal, B.; Nermell, B.; Yunus, M.; Rahman, A.; El Arifeen, S.; Persson, L.A.; Vahter, M. Nutritional status has marginal influence on the metabolism of inorganic arsenic in pregnant Bangladeshi women. Environ. Health Perspect. 2008, 116, 315-321. [CrossRef]

51. George, C.M.; Sima, L.; Arias, M.H.; Mihalic, J.; Cabrera, L.Z.; Danz, D.; Checkley, W.; Gilman, R.H. Arsenic exposure in drinking water: An unrecognized health threat in Peru. Bull. World Health Organ. 2014, 92, 565-572. [CrossRef]

52. Rasool, A.; Farooqi, A.; Masood, S.; Hussain, K. Arsenic in groundwater and its health risk assessment in drinking water of Mailsi, Punjab, Pakistan. Hum. Ecol. Risk Assess 2016, 22, 187-202. [CrossRef]

53. Tseng, C.H. A review on environmental factors regulating arsenic methylation in humans. Toxicol. Appl. Pharm. 2009, 235, 338-350. [CrossRef]

54. Yoshida, T.; Yamauchi, H.; Sun, G.F. Chronic health effects in people exposed to arsenic via the drinking water: Dose-response relationships in review. Toxicol. Appl. Pharm. 2004, 198, 243-252. [CrossRef] [PubMed]

55. Ahmed, S.; Akhtar, E.; Roy, A.; von Ehrenstein, O.S.; Vahter, M.; Wagatsuma, Y.; Raqib, R. Arsenic exposure alters lunch function and airway inflammation in children: A cohort study in rural Bangladesh. Environ. Int. 2017, 101, 108-116. [CrossRef] [PubMed]

56. Khan, K.M.; Chakraborty, R.; Bundschuh, J.; Bhattacharya, P.; Parvez, F. Health effects of arsenic exposure in Latin America: An overview of the past eight years of research. Sci. Total Environ. 2020, 25, 136071. [CrossRef]

57. Navas, A.A.; Sharrett, A.R.; Silbergeld, E.K.; Schwartz, B.S.; Nachman, K.E.; Burke, T.A.; Guallar, E. Arsenic exposure and cardiovascular disease: A systematic review of the epidemiologic evidence. Am. J. Epidemiol. 2005, 162, 1037-1049. [CrossRef]

58. Abhyankar, L.N.; Jones, M.R.; Guallar, E.; Navas, A.A. Arsenic Exposure and Hypertension: A Systematic Review. Environ. Health Perspect. 2001, 120, 494-500. [CrossRef]

59. Bhattacharjee, P.; Banerjee, M.; Giri, K. Role of genomic instability in arsenic-induced carcinogenicity: A review. Environ. Int. 2013, 53, 29-40. [CrossRef]

60. Chung, C.J.; Huang, C.J.; Pu, Y.S.; Su, C.T.; Huang, Y.K.; Chen, Y.T.; Hsueh, Y.M. Urinary 8-hydroxydeoxyguanosine and urothelial carcinoma risk in low arsenic exposure area. Toxicol. Appl. Pharm. 2008, 226, 14-21. [CrossRef]

61. Zhang, Q.; Wang, D.; Zheng, Q.; Zheng, Y.; Wang, H.; Xu, Y.; Li, X.; Sun, G. Joint effects of urinary arsenic methylation capacity with potential modifiers on arsenicosis: A cross-sectional study from an endemic arsenism area in Huhhot Basin, northern China. Environ. Res. 2014, 132, 281-289. [CrossRef]

62. Grashow, R.; Zhang, J.; Fangm, S.C.; Weisskopf, M.G.; Christiani, D.C.; Kile, M.L.; Cavallari, J.M. Inverse association between toenail arsenic and body mass index in a population of welders. Environ. Res. 2014, 131, 131-133. [CrossRef] [PubMed]

63. Ding, L.; Saunders, R.J.; Drobná, Z.; Walton, F.S.; Xun, P.; Thomas, D.J.; Stýblo, M. Methylation of arsenic by recombinant human wild-type arsenic ( +3 oxidation state) methyltransferase and its methionine 287 threonine (M287T) polymorph: Role of glutathione. Toxicol. Appl. Pharm. 2012, 264, 121-130. [CrossRef] [PubMed]

64. Ormachea, M.; Wern, H.; Johnsson, F.; Bhattacharya, P.; Sracek, O.; Thunvik, R.; Quintanilla, J.; Bundschuh, J. Geogenic arsenic and other trace elements in the shallow hydrogeologic system of Southern Poopó Basin, Bolivian Altiplano. J. Hazard Mater. 2013, 262, 924-940. [CrossRef]

65. Brinkman, G.L.; Coates, O. The effect of bronchitis, smoking and occupation in ventilation. Am. Rev. Respir. Dis. 1963, 87, 684-693. [CrossRef] [PubMed]

66. NCCMH (National Collaborating Centre for Mental Health) UK. Alcohol-Use Disorders: Diagnosis, Assessment and Management of Harmful Drinking and Alcohol Dependence. Leicester (UK): British Psychological Society 2011; (NICE Clinical Guidelines, No. 115.) 2, Alcohol Dependence and Harmful Alcohol Use. Available online: https://www.ncbi.nlm.nih.gov/books/NBK65500/ (accessed on 27 May 2020).

67. US-EPA (U. S. Environmental Protection Agency). Integrated Risk Information System. Arsenic, Inorganic. 2011, CASRN 7440-38-2. Available online: https://cfpub.epa.gov/ncea/iris2/chemicalLanding.cfm?substance nmbr $=278$ (accessed on 23 June 2020).

68. Sánchez-Rodas, D.; Oliveira, V.; Gómez, J.L. Development of a rapid method for arsenic speciation in chicken meat. Anal. Bioanal. Chem. 2006, 385, 1172-1177. [CrossRef] [PubMed] 
69. Lindberg, A.L.; Goessler, W.; Grander, M.; Nermell, B.; Vahter, M. Evaluation of the three most commonly used analytical methods for determination of inorganic arsenic and its metabolites in urine. Toxicol. Lett. 2007, 168, 310-318. [CrossRef]

70. Roco, A.; Quiñones, L.; Agúndez, J.; García-Martín, E.; Squicciarini, V.; Miranda, C.; Garay, J.; Farfán, N.; Caceres, D.D.; Varela, N.; et al. Frequencies of 23 functionally significant variant alleles related with metabolism of antineoplastic drugs in the Chilean population: Comparison with Caucasian and Asian populations. Front. Genet. 2012, 3, 1-9. [CrossRef]

71. Glickman, M.; Rao, S.; Schultz, M. False discovery rate control is a recommended alternative to Bonferroni-type adjustments in health studies. J. Clin. Epidemiol. 2014, 67, 850-857. [CrossRef]

72. R Core Team. R: A Language and Environment for Statistical Computing; R Foundation for Statistical Computing: Vienna, Austria, 2020; Available online: http://www.R-project.org/ (accessed on 2 May 2020).

73. Engström, K.; Nermell, B.; Concha, G.; Strömberg, U.; Vahter, M.; Broberg, K. Arsenic metabolism is influenced by polymorphism in genes involved in one-carbon metabolism and reduction reactions. Mutat. Res. 2009, 667, 4-14. [CrossRef]

74. Recio, R.; González, T.; Olivas, E.; Clark, R.; Gandolfi, J.; Ramirez, M. Association between polymorphisms in arsenic metabolism genes and urinary arsenic methylation profiles in girls and boys chronically exposed to arsenic. Environ. Mol. Mutagen. 2016, 57, 516-525. [CrossRef]

75. Meza, M.M.; Kopplin, M.J.; Burgess, J.L.; Gandolfi, A.J. Arsenic drinking water exposure and urinary excretion among adults in the Yaqui Valley, Sonora, Mexico. Environ. Res. 2004, 96, 119-126. [CrossRef] [PubMed]

76. Marchiset, N.; Savanovitch, C.; Sauvant, P. What is the best biomarker to assess arsenic exposure via drinking water? Environ. Int. 2012, 39. [CrossRef] [PubMed]

77. Lindberg, A.L.; Kumar, R.; Goessler, W.; Thirumaran, R.; Gurzau, E.; Koppova, K.; Rudnai, P.; Leonardi, G.; Fletcher, T.; Vahter, M. Metabolism of low-dose inorganic arsenic in a central European population: Influence of sex and genetic polymorphisms. Environ. Health Perspect. 2007, 115, 1081-1086. [CrossRef] [PubMed]

78. Rodrigues, E.G.; Kile, M.; Hoffman, E.; Quamruzzaman, Q.; Rahman, M.; Mahiuddin, G.; Hsueh, Y.; Christiani, D.C. GSTO and AS3MT genetic polymorphisms and differences in urinary arsenic concentrations among residents in Bangladesh. Biomarkers 2012, 17, 240-247. [CrossRef]

79. Hernández, A.; Xamena, N.; Sekaran, C.; Tokunaga, H.; Sampayo-Reyes, A.; Quinteros, D.; Creus, A.; Marcos, R. High arsenic metabolic efficiency in AS3MT287Thr allele carriers. Pharm. Genom. 2008, 18, 349-355. [CrossRef]

80. Lesseur, C.; Diamond, D.G.; Andrew, A.S.; Ekstrom, R.M.; Li, Z.; Kelsey, K.T.; Marsit, C.J.; Karagas, M.R. A case-control study of polymorphisms in xenobiotic and arsenic metabolism Genes and arsenic-related bladder cancer in New Hampshire. Toxicol. Lett. 2012, 210, 100-106. [CrossRef] [PubMed] 